OPEN ACCESS

Edited by:

Juarez Antonio Simões Quaresma, Instituto Evandro Chagas, Brazil

Reviewed by: Michael Poidinger, Singapore Immunology Network (A*STAR), Singapore

Yusei Ohshima,

University of Fukui, Japan Joana Vitte,

Aix-Marseille Université, France

*Correspondence:

Mahmoud A. Ghannoum mahmoud.ghannoum@case.edu

Specialty section:

This article was submitted to Microbial Immunology, a section of the journal Frontiers in Microbiology

Received: 04 April 2018 Accepted: 12 June 2018 Published: 10 July 2018

Citation:

Salem I, Ramser A, Isham N and Ghannoum MA (2018) The Gut Microbiome as a Major Regulator of the Gut-Skin Axis.

Front. Microbiol. 9:1459. doi: 10.3389/fmicb.2018.01459

\section{The Gut Microbiome as a Major Regulator of the Gut-Skin Axis}

\author{
Iman Salem ${ }^{1}$, Amy Ramser ${ }^{2}$, Nancy Isham ${ }^{1}$ and Mahmoud A. Ghannoum ${ }^{1,2 *}$ \\ ${ }^{1}$ Center for Medical Mycology, Department of Dermatology, Case Western Reserve University, Cleveland, OH, United States, \\ ${ }^{2}$ Dermatology, University Hospitals Cleveland Medical Center, Cleveland, $\mathrm{OH}$, United States
}

The adult intestine hosts a myriad of diverse bacterial species that reside mostly in the lower gut maintaining a symbiosis with the human habitat. In the current review, we describe the neoteric advancement in our comprehension of how the gut microbiota communicates with the skin as one of the main regulators in the gut-skin axis. We attempted to explore how this potential link affects skin differentiation and keratinization, its influence on modulating the cutaneous immune response in various diseases, and finally how to take advantage of this communication in the control of different skin conditions.

Keywords: gut microbiome, skin homeostasis, acne vulgaris, atopic dermatitis, psoriasis, probiotics

\section{INTRODUCTION}

The gut and skin, densely vascularized and richly innervated organs with crucial immune and neuroendocrine roles, are uniquely related in purpose and function (O'Neill et al., 2016). As our primary interface with the external environment, both organs are essential to the maintenance of physiologic homeostasis. Cumulative evidence has demonstrated an intimate, bidirectional connection between the gut and skin, and numerous studies link gastrointestinal (GI) health to skin homeostasis and allostasis (Figure 1) (Levkovich et al., 2013; O’Neill et al., 2016). GI disorders are often accompanied by cutaneous manifestations and the GI system, particularly the gut microbiome, appears to participate in the pathophysiology of many inflammatory disorders (Shah et al., 2013; Thrash et al., 2013; Gloster et al., 2016). In this review, we will discuss the gut microbiome's contribution to three common skin disorders - acne, atopic dermatitis (AD), and psoriasis - (Figure 1) as well as review data on how the microbiome's influence can be harnessed for therapeutic purpose via probiotic supplementation.

\section{GUT MICROBIAL ECOLOGY}

Our gut microbiome is a vast collection of bacteria, viruses, fungi, and protozoa colonizing our GI system (Ipci et al., 2017). This collection of microbes outnumbers host cells 10-fold and contains genetic material 150 times greater than the host's own karyosome (Wu and Lewis, 2013; Ipci et al., 2017). Recent advances in metagenomics and the advent of high-throughput DNA-sequencing technology has enhanced our understanding of the microbiome and its dynamic influence on human health and pathology (Boyle et al., 2011; Moore-Connors et al., 2016).

The intestinal microbiome provides important metabolic and immune benefits to the host. Gut flora contribute to the breakdown of indigestible complex polysaccharides and are vital to the production of certain nutritional components such as vitamin $\mathrm{K}$. The gut microbiome's 


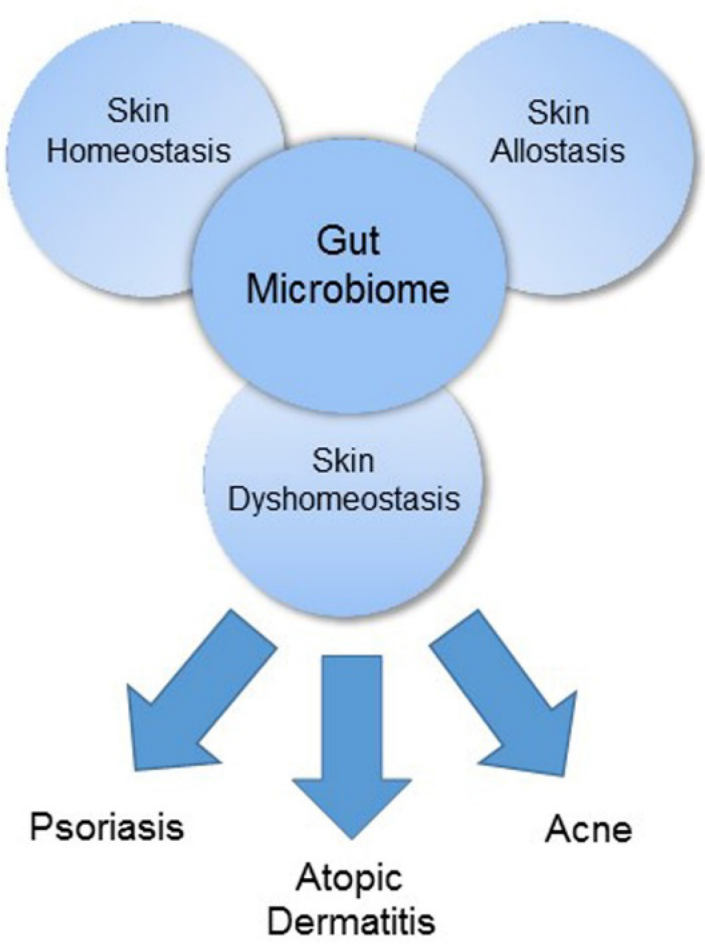

FIGURE 1 | The gut microbiome as a major regulator of the gut-skin axis.

influence on the host immune system is vast, and the relationship is intricately regulated to both enable immune tolerance of dietary and environmental antigens and provide protection against potential pathogens. The intestinal microbiome protects against invasion by exogenous pathogens directly, by competitively binding to epithelial cells, and indirectly, by triggering immunoprotective responses (Boyle et al., 2011; Kosiewicz et al., 2014).

Commensal bacteria prime the gut immune system through specific interactions between bacterial antigens and pattern recognition receptors expressed by a variety of host cells (Kosiewicz et al., 2014). For example, gut microbes are a source of peptidoglycan capable of altering the expression of toll-like receptors (TLRs), pattern recognition receptors on the surface of many innate immune cells. TLRs recognize pathogen associated molecular patterns and trigger cascades of events linking the innate to the adaptive immune system through the activation of the nuclear factor kappa B (NF- $\kappa$ B) signaling pathway (Macpherson and Harris, 2004; Clarke et al., 2010; Thomas and Versalovic, 2010; Boyle et al., 2011; Kosiewicz et al., 2014). The contribution of the gut microbiome to the adaptive immune system has been well-characterized and involves the induction of immunoglobulin A and the maintenance of homeostasis between effector T cells (Th1, Th2, and Th17) and regulatory $\mathrm{T}$ cells (Kosiewicz et al., 2014). Certain microbes can also contribute to intestinal epithelial barrier function via "cross-talk" with elements of mucosal immunity (Bik, 2009; Purchiaroni et al., 2013; Kosiewicz et al., 2014; Rajilić-Stojanović and de Vos, 2014;
Sirisinha, 2016). For instance, one commensal gut microbe, Lactobacillus LGG, secretes p40, a protein capable of suppressing cytokine-mediated apoptosis and epithelial barrier disruption. Another species, Escherichia coli Nissle, contains flagella capable of inducing $\beta$-defensin 2 in epithelial cells (Kosiewicz et al., 2014).

Many human and animal studies suggest that the intestinal microbiome's influence extends beyond the gut, and in fact contributes to the function, and dysfunction, of distant organ systems (Levkovich et al., 2013; Kim Y.G. et al., 2014). Short chain fatty acids (SCFAs), products of dietary fibers fermented by components of the gut microbiome, demonstrate a protective role against the development of inflammatory disorders including arthritis and allergy, in addition to colitis (Kim Y.G. et al., 2014). Intestinal dysbiosis, in the form of unbalanced bacterial composition or aberrant immune reactions to commensal flora, has been linked to metabolic, neurodegenerative, and neoplastic diseases. Altered gut flora may favor the production of effector over regulatory $\mathrm{T}$ cells, thereby contributing to the development of autoimmune disorders. For example, segmented filamentous bacteria in the gut have been associated with a variety of Th17mediated diseases. Through mechanisms not yet completely understood, the gut microbiome's influence clearly extends beyond the GI system. One distant organ known to have a particularly complex connection with the gut is the skin (Levkovich et al., 2013; Kim Y.G. et al., 2014; Kosiewicz et al., 2014).

\section{ROLE OF THE GUT MICROBIOME IN SKIN HOMEOSTASIS}

The skin effectively performs its functions - protection, temperature regulation, water retention, and more - when in a state of homeostasis. As an organ undergoing constant renewal, effective epidermal turnover, the process by which the skin regenerates itself, is essential to maintaining this state. Epidermal cells originate from stem cells in the basal layer of the epidermis and then undergo morphologic change while migrating to the skin surface. Cells differentiate into three cell types - basal cells, spinous cells, and granule cells - before ultimately becoming the corneocytes that make up the outermost layer of the epidermis, the stratum corneum. This process of epidermal differentiation, also referred to as keratinization, is under the control of dedicated transcriptional programs. For example, the expression of KRT5/K5 and KRT14, the genes which encode keratin 5 and keratin 14, respectively, is downregulated as migrating cells move outward, while the expression of genes encoding KRT1 and KRT10 is upregulated (Baba et al., 2012; Weaver et al., 2013; Gaur et al., 2014; Abhishek et al., 2016). Ultimately, this highly regulated process results in a stratum corneum consisting of approximately 15 layers of densely keratinized, stratified, and anucleated corneocytes held together with multiple lipid bilayers in a "brick and mortar" model. The corneocytes serve as the bricks, while ceramides, cholesterol, fatty acids, and cholesterol esters make up the mortar that holds the bricks together. When epidermal turnover functions appropriately, 
the resulting brick and mortar structure serves as an effective skin barrier with the ability to limit evaporation, preserve skin moisture, and protect from invasion by foreign organisms and substances (Baba et al., 2012; Weaver et al., 2013; Gaur et al., 2014). Through its influence on the signaling pathways that coordinate this process essential to skin homeostasis, the gut microbiome impacts integumentary health (O'Neill et al., 2016).

Though not yet fully explored, the mechanisms by which intestinal microbiota exert their influence on skin homeostasis appear to be related to the modulatory effect of gut commensals on systemic immunity (O'Neill et al., 2016). Certain gut microbes and metabolites - retinoic acid, polysaccharide A from Bacteroides fragilis, Faecalibacterium prausnitzii, and bacteria belonging to Clostridium cluster IV and XI promote the accumulation of regulatory $\mathrm{T}$ cells, lymphocytes which facilitate anti-inflammatory responses (Forbes et al., 2015). Segmented filamentous bacteria, alternatively, promote the accumulation of pro-inflammatory Th17 and Th1 cells. SCFAs, particularly butyrate, suppress immune responses by inhibiting inflammatory cells' proliferation, migration, adhesion, and cytokine production. In addition, through their inhibition of histone deacetylase and inactivation of NF- $\mathrm{B}$ signaling pathways, SCFAs regulate both the activation and apoptosis of immune cells. The inhibition of histone deacetylase promotes the proliferation of regulatory cells involved in various cutaneous physiologic functions including regulation of hair follicle stem cell differentiation and wound healing (Meijer et al., 2010; Loser and Beissert, 2012; Samuelson et al., 2015). In addition, there is new evidence that the intestinal microbiome may impact cutaneous physiology, pathology, and immune response more directly, through the metastasis of gut microbiota and their metabolites to the skin (Samuelson et al., 2015; O'Neill et al., 2016). In cases of disturbed intestinal barriers, intestinal bacteria as well as intestinal microbiota metabolites have been reported to gain access to the bloodstream, accumulate in the skin, and disrupt skin homeostasis (O'Neill et al., 2016). DNA of intestinal bacteria has been successfully isolated from the plasma of psoriatic patients (O'Neill et al., 2016). These findings represent evidence of a more direct link between the gut microbiome and cutaneous homeostasis that has just begun to be explored.

The gut microbiome appears to influence the skin microbiome as well. SCFAs resulting from fiber fermentation in the gut propionate, acetate, and butyrate - are believed to play a pivotal role in determining the predominance of certain skin microbiomic profiles which subsequently influence cutaneous immune defense mechanisms. Propionibacterium, for example, is a genus capable of producing SCFAs, predominantly acetate and propionic acid. Propionic acid can exhibit a profound antimicrobial effect against USA300, the most prevailing community-acquired methicillin-resistant Staphylococcus aureus (Shu et al., 2013; Samuelson et al., 2015; Schwarz et al., 2017). S. epidermidis and P. acnes are examples of cutaneous commensals known to tolerate wider SCFA shifts than other flora. Altogether, these findings provide supportive evidence for a functional interactive mechanism between gut and skin.
The beneficial effects of gut bacteria on skin health and appearance have been documented in several rodent and human studies (Tables 1, 2). In a study by Levkovich et al. (2013), mice who received Lactobacillus reuteri supplementation experienced increased dermal thickness, enhanced folliculogenesis, and increased sebocyte production which manifested as thicker, shinier fur. In another rodent study, Horii et al. (2014) reported that oral supplementation of Lactobacillus brevis SBC8803 in rats resulted in decreased cutaneous arterial sympathetic nerve tone and increased cutaneous blood flow, possibly via increased serotonin release from intestinal enterochromaffin cells and subsequent activation of parasympathetic pathways. A significant decrease in transepidermal water loss (TEWL), a marker of skin barrier function, was noted as well (Horii et al., 2014). This effect was reproduced in human clinical research. After taking L. brevis SBC8803 oral supplements for 12 weeks, human subjects had significantly decreased TEWL and significantly increased corneal hydration (Ogawa et al., 2016). In a separate placebocontrolled human study, bacterial supplementation was shown to have a positive effect on skin barrier function (Guéniche et al., 2013). Volunteers who took Lactobacillus paracasei NCC2461 supplements for 2 months had decreased skin sensitivity and TEWL, an effect attributed to an observed increase in circulating transforming growth factor beta (TGF- $\beta$ ), a cytokine known to have a favorable effect on barrier integrity (Guéniche et al., 2013; O'Neill et al., 2016). A study by Baba et al. (2006) found that when Lactobacillus helveticus-fermented milk whey was introduced to human epidermal keratinocyte cultures, there was increased expression of keratin 10 and involucrin, markers of early and late differentiation, respectively, suggesting that L. helveticus can promote epidermal differentiation. In addition, there was a dose-dependent increase in profilaggrin, a protein involved in the terminal differentiation of keratinocytes. Profilaggrin is ultimately cleaved to form filaggrin (FLG), a protein essential to normal epidermal flexibility and hydration, suggesting a potential moisturizing benefit of this bacteria as well (Baba et al., 2006).

\section{GUT MICROBIOTA AND SKIN ALLOSTASIS}

The intestinal microbiome contributes to skin allostasis, the restoration of homeostasis after a disturbance or stressor, through gut microbiota-mediated effects on both innate and adaptive immunity (Benyacoub et al., 2014; Kim Y.G. et al., 2014; Chen et al., 2017). Studies have demonstrated that gut bacteria can positively impact the response to disturbed skin barrier function. For example, a study by Baba et al. (2010) demonstrated that the administration of Lactobacillus helveticus decreased the severity of sodium dodecyl sulfate-induced dermatitis and subsequent TEWL. Another study showed improved recovery of skin barrier function and decreased signs of reactive skin inflammation including mast cell degranulation, vasodilation, edema, and tumor necrosis factor alpha (TNF- $\alpha$ ) release - following the administration of Lactobacillus paracasei CNCM I-2116 (ST11) (Branchet-Gumila et al., 1999; Guéniche et al., 2010; Philippe et al., 2011). Research conducted by Poutahidis et al. (2013) found 
TABLE 1 | Evidence of beneficial probiotic interventions: animal studies.

\begin{tabular}{|c|c|c|c|c|}
\hline Author & Population & Oral probiotic & Clinical response & Proposed mechanism \\
\hline Chapat et al., 2004 & $\begin{array}{l}\text { C57BL/6 female mice, } \\
\mathrm{MHC} \text { classll-deficient } \\
\left(\mathrm{A} \beta^{\circ / \circ}\right) \text { mice }\end{array}$ & $\begin{array}{l}\text { L. casei } * \mathrm{DN}-114001(200 \mu \mathrm{l} \\
\text { fermented milk/d with } \\
\left.2 \times 10^{8} \mathrm{CFU} / \mathrm{d} \times 26 \text { days }\right)\end{array}$ & $\begin{array}{l}50 \% \text { inhibition of contact } \\
\text { hypersensitivity response to } \\
\text { 2,4-DNFB* }\end{array}$ & $\begin{array}{l}\downarrow \text { Hapten-specific CD8+ T cell } \\
\text { proliferation }\end{array}$ \\
\hline Guéniche et al., 2006 & Hairless Skh:hr1 mice & $\begin{array}{l}\text { L. johnsonii (La1) }\left(1 \times 10^{8}\right. \\
\text { CFU/d } \times 10 \text { days })\end{array}$ & $\begin{array}{l}\text { Protected against UVR-induced } \\
\text { contact hypersensitivity }\end{array}$ & $\begin{array}{l}\downarrow \text { Epidermal LCs* density and } \uparrow \\
\text { IL-10 plasma levels }\end{array}$ \\
\hline Baba et al., 2010 & Hos:HR-1 hairless mice & $\begin{array}{l}\text { L. helveticus-fermented milk } \\
\text { whey (in distilled water } \\
\text { ad libitum } \times 5 \text { weeks }\end{array}$ & $\begin{array}{l}\downarrow \text { TEWL* }, \downarrow \text { severity of sodium } \\
\text { dodecyl sulfate-induced } \\
\text { dermatitis }\end{array}$ & $\begin{array}{l}\uparrow \text { Keratinocyte differentiation and } \\
\text { expression of profilaggrin }\end{array}$ \\
\hline Won et al., 2011 & $\begin{array}{l}\text { NC/Nga mice (AD mouse } \\
\text { model) }\end{array}$ & $\begin{array}{l}\text { L. plantarum CJLP55, CJLP133 } \\
\text { and CJLP136 }\left(1 \times 10^{10}\right. \\
\text { CFU/d } \times 55 \text { days })\end{array}$ & $\begin{array}{l}\text { Suppression of house-dust } \\
\text { mite-induced dermatitis, } \downarrow \\
\text { epidermal thickening }\end{array}$ & $\begin{array}{l}\uparrow \mathrm{IL}-10 \text { production and alteration of } \\
\text { the Th1/Th2 balance }\end{array}$ \\
\hline Kim et al., 2012 & $\begin{array}{l}\text { SKH-1 hairless mice (AD } \\
\text { mouse model) }\end{array}$ & $\begin{array}{l}\text { L. rhamnosus (Lcr35) }\left(1 \times 10^{9}\right. \\
\text { CFU/d) }\end{array}$ & $\begin{array}{l}\downarrow \text { TEWL, erythema and } \\
\text { inflammation after exposure to } \\
\text { topical allergen ovalbumin }\end{array}$ & $\begin{array}{l}\downarrow \mathrm{IL}-4 \text { and TSLP* via mechanism } \\
\text { involving } \uparrow \text { CD4+CD25+Foxp3+ } \\
\text { regulatory } T \text { cells }\end{array}$ \\
\hline Levkovich et al., 2013 & $\begin{array}{l}\text { C57BL/6 wild type and } \\
\text { IL-10-deficient mice }\end{array}$ & $\begin{array}{l}\text { L. reuteri ATCC } 6475\left(3.5 \times 10^{5}\right. \\
\text { organisms } / d \times 20-24 \text { weeks })\end{array}$ & $\begin{array}{l}\text { Thicker, shinier fur. } \uparrow \text { dermal } \\
\text { thickness, folliculogenesis, and } \\
\text { sebocyte production. }\end{array}$ & $\begin{array}{l}\text { IL-10 dependent anti-inflammatory } \\
\text { pathway }\end{array}$ \\
\hline Poutahidis et al., 2013 & $\begin{array}{l}\text { C57BL/6 wild type, } \\
\text { oxytocin-deficient WT } \\
\text { and KO *B6; } \\
\text { 129S-Oxttm1Wsy/J mice }\end{array}$ & $\begin{array}{l}\text { L. reuteri ATCC-PTA- } 6475 \\
\left(3.5 \times 10^{5} \text { organisms } / d \text { in }\right. \\
\text { drinking water } \times 2-3 \text { weeks })\end{array}$ & Accelerated wound healing & $\begin{array}{l}\text { Oxytocin-mediated regulatory } \top \text { cell } \\
\text { trafficking ( } \uparrow \text { Foxp3+ regulatory } \top \\
\text { cells) }\end{array}$ \\
\hline Horii et al., 2014 & $\begin{array}{l}\text { Wistar rats and hairless } \\
\text { Wistar Yagi (HWY) rats }\end{array}$ & $\begin{array}{l}\text { L. brevis SBC8803 }(0.1 \mathrm{mg} / \mathrm{mL} \text { in } \\
\text { drinking water) }\end{array}$ & $\begin{array}{l}\downarrow \text { Cutaneous arterial sympathetic } \\
\text { nerve activity, } \uparrow \text { cutaneous blood } \\
\text { flow, } \downarrow \text { TEWL }\end{array}$ & Activation of 5-HT3 receptors \\
\hline Kim H.M. et al., 2014 & Hairless mice & $\begin{array}{l}\text { L. plantarum HY7714 (100 } \mu \mathrm{l} \\
\mathrm{PBS}^{*} / \mathrm{d} \text { with } 1 \times 10^{9} \mathrm{CFU}, 1 \mathrm{~h} \\
\text { prior to UVB irradiation) }\end{array}$ & $\begin{array}{l}\downarrow \text { Development of wrinkles } \\
\text { (number, depth and area) } \\
\text { following UVB radiation; } \downarrow \\
\text { UVB-induced epidermal } \\
\text { thickness }\end{array}$ & $\begin{array}{l}\text { Inhibition of MMP- } 13 \text { expression, } \\
\text { MMP-2 activity, and MMP- } 9 \text { activity } \\
\text { in dermal tissue }\end{array}$ \\
\hline Lee et al., 2016 & $\begin{array}{l}\mathrm{NC} / \mathrm{Nga} \text { mice (AD mouse } \\
\text { model) }\end{array}$ & $\begin{array}{l}\text { L. rhamnosus IDCC } 3201 \\
\left(1 \times 10^{8}, 1 \times 10^{9} \text {, or } 1 \times 10^{10}\right. \\
\text { cells } / \mathrm{d} \times 8 \text { weeks })\end{array}$ & $\begin{array}{l}\text { Dose-dependent: } \downarrow \text { Dermatitis } \\
\text { scores, } \downarrow \text { frequency of } \\
\text { scratching, } \downarrow \text { epidermal thickness }\end{array}$ & $\begin{array}{l}\text { Suppression of mast cell mediated } \\
\text { inflammation ( } \downarrow \text { mast cells, } \downarrow \text { lgE, } \downarrow \\
\text { IL4) }\end{array}$ \\
\hline Chen et al., 2017 & $\begin{array}{l}\text { BALB/c } \\
\text { imiquimod-induced } \\
\text { psoriasis-like mice }\end{array}$ & $\begin{array}{l}\text { L. pentosus GMNL-77 }\left(5 \times 10^{7}\right. \\
\text { CFU/0.2 mL/d or } 5 \times 10^{8} \\
\text { CFU/0.2 mL/d } \times 7 \text { days })\end{array}$ & $\downarrow$ Erythema, $\downarrow$ scaling & $\begin{array}{l}\downarrow \text { Expression of pro-inflammatory } \\
\text { cytokines (TNF- } \alpha, \text { IL- } 6 \text {, and } \\
\text { IL-23/IL-17A axis-associated } \\
\text { cytokines) mediated by suppression } \\
\text { of APCs*(CD103+ dendritic cells) or } \\
\text { direct effect on differentiation or } \\
\text { proliferation of T cells }\end{array}$ \\
\hline
\end{tabular}

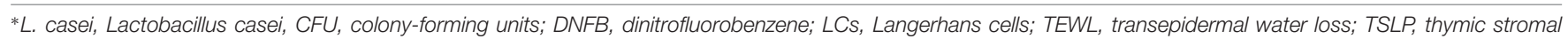
lymphopoietin; PBS, phosphate-buffered saline; APCs, antigen-presenting cells.

that mice experienced accelerated wound healing following the consumption of Lactobacillus reuteri. Microscopic examination of wounds throughout the healing process revealed the usual histomorphologic stages of wound healing in both probiotictreated and untreated mice, however, the time required for complete healing was markedly reduced in the treated group. Foxp $3+$ regulatory $\mathrm{T}$ cells were the prominent immune cell population in wound sites among the treated group, while neutrophils were almost completely absent. L. reuteri-induced oxytocin-mediated regulatory $\mathrm{T}$ cell trafficking resulted in the rapid clearance of neutrophils from the wounds of the treated group, ultimately resulting in decreased time-to-heal (Poutahidis et al., 2013).

The gut microbiome has also been shown to support restoration of skin homeostasis after ultraviolet (UV) radiation exposure. In one study, 10 days of oral supplementation with Lactobacillus johnsonii in hairless mice protected the mice against UV-induced contact hypersensitivity, an effect attributed to reduced epidermal Langerhans cells and increased systemic IL-10 levels (Guéniche et al., 2006). In a placebo-controlled study, Lactobacillus johnsonii La1 supplementation protected cutaneous immune homeostasis in 54 healthy volunteers following UV radiation exposure. This effect was mediated by the normalization of epidermal expression of CD1a, a transmembrane glycoprotein structurally similar to major histocompatibility complex that presents self and microbial glycolipids to T cells (Dougan et al., 2007; Peguet-Navarro et al., 2008).

Commensal gut flora can promote skin allostasis by influencing $\mathrm{T}$ cell differentiation in response to various immune stimuli. Oral administration of Lactobacillus casei DN-114 001 has been shown to impair differentiation of CD8 + $\mathrm{T}$ cells into cutaneous hypersensitivity effector cells and decrease their recruitment to the skin when exposed 
TABLE 2 | Evidence of beneficial probiotic interventions: human studies.

\begin{tabular}{|c|c|c|c|c|}
\hline Author & Study design & Oral probiotic & Clinical response & Proposed mechanism \\
\hline Siver, 1961 & $\begin{array}{l}\text { Intervention group only; } \\
300 \text { subjects with acne }\end{array}$ & $\begin{array}{l}\text { L. acidophilus and } \\
\text { L. bulgaricus* } \\
\text { (probiotic } \times 8 \text { days, } 2 \text {-weeks } \\
\text { washout, then } \\
\text { re-introduction } \times 8 \text { days) }\end{array}$ & $\begin{array}{l}\text { clinical improvement in } 80 \% \text { of } \\
\text { patients, particularly those with } \\
\text { inflammatory acne }\end{array}$ & Mechanism not established \\
\hline $\begin{array}{l}\text { Peguet-Navarro } \\
\text { et al., } 2008\end{array}$ & $\begin{array}{l}\text { Randomized, double-blind, } \\
\text { placebo-controlled; } 54 \\
\text { healthy subjects }\end{array}$ & L. johnsonii (La1) for 6 weeks & $\begin{array}{l}\uparrow \text { Recovery of skin immune } \\
\text { homeostasis following } \\
\text { UV-induced } \\
\text { immunosuppression }\end{array}$ & $\begin{array}{l}\text { Normalization of epidermal } \\
\text { expression of CD1a }\end{array}$ \\
\hline $\begin{array}{l}\text { Vijayashankar and } \\
\text { Raghunath, } 2012\end{array}$ & $\begin{array}{l}\text { Case report; 47-year-old } \\
\text { female with severe pustular } \\
\text { psoriasis }\end{array}$ & $\begin{array}{l}\text { L. sporogenes } \\
\text { (Supplementation } 3 \times / d \text { ) }\end{array}$ & $\begin{array}{l}\text { Clinical improvement at } 15 \\
\text { days, almost complete } \\
\text { clearance at } 4 \text { weeks }\end{array}$ & Mechanism not established \\
\hline $\begin{array}{l}\text { Groeger et al., } \\
2013\end{array}$ & $\begin{array}{l}\text { Randomized, double-blind, } \\
\text { placebo-controlled; } 26 \\
\text { subjects with plaque } \\
\text { psoriasis }\end{array}$ & $\begin{array}{l}\text { B. infantis *35624 }\left(1 \times 10^{10}\right. \\
\text { CFU*/d } \times 8 \text { weeks })\end{array}$ & $\begin{array}{l}\downarrow \text { Systemic inflammation ( } \downarrow \\
\left.\text { CRP* }^{*} \downarrow \downarrow \text { TNF- } \alpha^{*}\right)\end{array}$ & $\begin{array}{l}\text { Induction of mucosal } \\
\text { immunoregulatory responses } \\
\text { that can exert systemic effects }\end{array}$ \\
\hline $\begin{array}{l}\text { Guéniche et al., } \\
2013\end{array}$ & $\begin{array}{l}\text { Randomized, double-blind, } \\
\text { placebo-controlled; } 64 \\
\text { females with sensitive skin }\end{array}$ & $\begin{array}{l}\text { L. paracasei NCC2461 (ST11) } \\
\left(1 \times 10^{10} \mathrm{CFU} / \mathrm{d} \times 2 \text { months) }\right.\end{array}$ & $\downarrow$ Skin sensitivity, $\downarrow$ TEWL* & $\begin{array}{l}\downarrow \text { Skin sensitivity } \\
\text { neuromediators and neurogenic } \\
\text { inflammation, positive effect on } \\
\text { skin barrier function via } \uparrow \\
\text { circulating TGF- } \beta^{*}\end{array}$ \\
\hline Jung et al., 2013 & $\begin{array}{l}\text { Randomized, controlled, } \\
\text { open-label; } 45 \text { females with } \\
\text { acne }\end{array}$ & $\begin{array}{l}\text { L. acidophilus (NAS), LB- } 51^{*} \text {, } \\
\text { B. bifidum, }\left(5 \times 10^{9}, 5 \times 10^{9} \text {, }\right. \\
20 \times 10^{9} \text { CFU } 2 \times / d \times 12 \text { weeks }\end{array}$ & $\begin{array}{l}\text { Significant } \downarrow \text { in number of acne } \\
\text { lesions with using probiotic } \\
\text { together with Abs than Abs } \\
\text { alone }\end{array}$ & $\begin{array}{l}\text { Synergistic anti-inflammatory } \\
\text { effect }\end{array}$ \\
\hline Lee et al., 2015 & $\begin{array}{l}\text { Randomized, double-blind, } \\
\text { placebo-controlled; } 129 \\
\text { females with dry skin and } \\
\text { wrinkles }\end{array}$ & $\begin{array}{l}\text { L. plantarum } \mathrm{HY} 7714\left(1 \times 10^{10}\right. \\
\text { CFU/d } \times 12 \text { weeks })\end{array}$ & $\begin{array}{l}\uparrow \text { Skin hydration, } \downarrow \text { TEWL, } \uparrow \\
\text { skin elasticity, } \downarrow \text { wrinkle depth }\end{array}$ & $\begin{array}{l}\text { Molecular control of signaling } \\
\text { pathways and gene expression } \\
\text { in skin cells }\end{array}$ \\
\hline $\begin{array}{l}\text { Fabbrocini et al., } \\
2016\end{array}$ & $\begin{array}{l}\text { Randomized, double-blind, } \\
\text { placebo-controlled; } 20 \\
\text { adults with acne }\end{array}$ & $\begin{array}{l}\text { L. rhamnosus SP1 }\left(3 \times 10^{9}\right. \\
\text { CFU/d }(75 \mathrm{mg} / \mathrm{d}) \times 12 \text { weeks })\end{array}$ & $\begin{array}{l}\text { Improved appearance of adult } \\
\text { acne }\end{array}$ & $\begin{array}{l}\text { Normalized skin expression of } \\
\text { genes involved in insulin } \\
\text { signaling ( } \downarrow \text { IGF-1* expression, } \\
\uparrow \text { FOXO1) }\end{array}$ \\
\hline Ogawa et al., 2016 & $\begin{array}{l}\text { Randomized, double-blind, } \\
\text { placebo-controlled; } 126 \\
\text { subjects with elevated } \\
\text { TEWL }\end{array}$ & $\begin{array}{l}\text { L. brevis SBC8803 ( } 25 \text { or } \\
50 \mathrm{mg} / \mathrm{d} \times 12 \text { weeks) }\end{array}$ & $\downarrow$ TEWL, $\uparrow$ corneal hydration & $\begin{array}{l}\text { Stimulation of serotonin release } \\
\text { from intestinal enterochromaffin } \\
\text { cells } \rightarrow \uparrow \text { vagal nerve activity }\end{array}$ \\
\hline
\end{tabular}

* L. bulgaricus, Lactobacillus bulgaricus; $B$. infantis, Bifidobacterium infantis; CFU, colony-forming units; CRP, C-reactive protein; TNF- $\alpha$, tumor necrosis factor alpha; LB, Lactobacillus bulgaricus; TEWL, transepidermal water loss; TGF- $\beta$, transforming growth factor beta.

to 2-4-dinitrofluorobenzene (Table 1). This microbe also increased recruitment of FoxP3 + regulatory $\mathrm{T}$ cells to the skin, resulting in decreased apoptosis-mediated skin inflammation, thereby restoring homeostasis through immune-modulatory mechanisms (Chapat et al., 2004; Hacini-Rachinel et al., 2009).

Th17 cells are abundant in both the skin and intestine, as both organs contact the external environment (Weaver et al., 2013). These cells and their pro-inflammatory cytokines are thought to directly contribute to the pathogenesis of several chronic inflammatory dermatoses including psoriasis, Behcet's disease, and contact hypersensitivity (Van Beelen et al., 2007; Esplugues et al., 2011; Huang et al., 2012). The balance between Th17 effector cells and their counterpart regulatory $\mathrm{T}$ cells is greatly influenced by the intestinal microbiome (Van Beelen et al., 2007). Th17 cells can be eliminated in the intestinal lumen, or they may acquire a regulatory phenotype with immunosuppressive characteristics (rTh17) that restricts pathogenicity (Esplugues et al., 2011).

\section{DYSBIOSIS AND SKIN DYSHOMEOSTASIS}

Intestinal dysbiosis, a state of microbial imbalance, has the potential to negatively impact skin function. Free phenol and p-cresol, metabolic products of aromatic amino acids, are considered biomarkers of a disturbed gut milieu as their production is induced by certain pathogenic bacteria, most notably Clostridium difficile. These metabolites can access the circulation, preferentially accumulate in the skin, and impair epidermal differentiation and skin barrier integrity (O'Neill et al., 2016). Indeed, high p-cresol serum levels are associated with reduced skin hydration and impaired keratinization (Dawson et al., 2011; Miyazaki et al., 2014). Intestinal dysbiosis results in increased epithelial permeability which then triggers the activation of effector $\mathrm{T}$ cells, disrupting their balance with immunosuppressive regulatory $\mathrm{T}$ cells. Pro-inflammatory cytokines further enhance epithelial permeability and set up a 
vicious cycle of chronic systemic inflammation (Kosiewicz et al., 2014; O'Neill et al., 2016). These are just a few mechanisms by which a disturbed gut microbiome manifests in impaired skin function. Here, we will discuss mechanisms by which intestinal dysbiosis contributes to three common skin disorders - acne, $\mathrm{AD}$, and psoriasis.

\section{Acne Vulgaris}

Acne vulgaris is a chronic disease of the pilosebaceous unit that manifests clinically as non-inflammatory comedones or inflammatory papules, pustules, and nodules (Yentzer et al., 2010; Bhate and Williams, 2013). Three primary factors are implicated in its pathophysiology - sebum oversecretion, abnormal keratinocyte desquamation leading to ductal obstruction, and superimposed inflammation mediated by Propionibacterium acnes (Dawson and Dellavalle, 2013; Agak et al., 2014; Fox et al., 2016; Dreno et al., 2017; Picardo et al., 2017; Rodan et al., 2017).

Approximately $85 \%$ of adolescents and young adults between the ages of 12 and 25 are affected by acne, and it represents the eighth most common medical disorder worldwide (Hay et al., 2014; Tan and Bhate, 2015; Lynn et al., 2016; Zaenglein et al., 2016). Acne is particularly prevalent in western countries, a phenomenon thought to be related to an abundance of carbohydrates in the typical western diet. A high glycemic load promotes an increase in insulin/insulinlike growth factor (IGF-1) signaling. This is thought to induce increased cytoplasmic expression of the metabolic forkhead box transcription factor (FoxO1), a sensor of cell nutrition state. FoxO1 ultimately triggers mammalian target of rapamycin complex 1 (mTORC1), a governor of metabolism and cell proliferation, to mediate sebaceous gland hyperproliferation, lipogenesis, and hyperplasia of acroinfundibular keratinocytes, thereby contributing to the development of acne (Melnik, 2015; Agamia et al., 2016; Zaenglein et al., 2016).

Gut microbiota influence the pathophysiology of acne via cross talk between intestinal commensal bacteria and the mTOR pathway (Noureldein and Eid, 2018). Metabolites produced by gut microbiota have been shown to regulate cell proliferation, lipid metabolism, and other metabolic functions mediated by the mTOR pathway. The mTOR pathway can in turn affect the composition of intestinal microbiota through regulation of the intestinal barrier. In cases of intestinal dysbiosis and disrupted gut barrier integrity, this bidirectional relationship can result in a positive feedback cycle of metabolic inflammation. Given the important role of mTORC1 in the pathogenesis of acne, this relationship serves as a mechanism by which the gut microbiome can influence acne pathophysiology.

The complex connection between acne and GI dysfunction may also be mediated by the brain, an idea first postulated by Stokes and Pillsbury (1930). Supporting this hypothesis is the frequent association of both psychological comorbidities anxiety and depression - and GI distress with acne. These psychological stressors are hypothesized to cause the intestinal flora to either produce different neurotransmitters serotonin, norepinephrine and acetylcholine - or trigger nearby enteroendocrine cells to release neuropeptides. These neurotransmitters not only increase intestinal permeability, leading to both intestinal and systemic inflammation, but also directly access the circulation through the compromised intestinal barrier resulting in systemic effects (Zhang et al., 2008; Do et al., 2009; Bowe and Logan, 2011; Bowe et al., 2012, 2014; Zouboulis, 2014; Duman et al., 2016; Jena and Sahoo, 2016; Prakash et al., 2016; Ramrakha et al., 2016; Vaughn et al., 2017). The gut-brain-skin axis hypothesis remained dormant for several decades but has been validated by recent advances in microbiome research and our understanding of its effect on health and disease (Bowe and Logan, 2011; Bowe et al., 2014). Consistent with this hypothesis, an upregulation of substance $\mathrm{P}$ containing nerves and a strong expression of this neuropeptide is mutually seen in both acne vulgaris and intestinal dysbiosis. Substance $\mathrm{P}$ can trigger inflammatory signals that result in the increase of pro-inflammatory mediators implicated in the pathogenesis of acne (IL-1, IL-6, TNF- $\alpha$, PPAR- $\gamma$ ) (Lee et al., 2008; Arck et al., 2010; Bercik and Collins, 2014; Borovaya et al., 2014; Theodorou et al., 2014; Petra et al., 2015; Rokowska-Waluch et al., 2016).

Alternatively, the link may originate with GI dysfunction which then leads to psychological and cutaneous disorders. Hypochlorhydria is frequently associated with acne. Low levels of acidity allows for the migration of colonic bacteria to distal parts of the small intestine, creating a state of intestinal dysbiosis and small intestinal bacterial overgrowth (SIBO). A larger bacterial population competes for nutrients and impairs the absorption of fats, proteins, carbohydrates, and vitamins. Malabsorbed nutrients, including folic acid, zinc, chromium, selenium, and $\omega$ 3 fatty acids have been shown to influence one's psychological state and, along with systemic oxidative stress, have been implicated in the pathophysiology of acne vulgaris (Katzman and Logan, 2007). SIBO also results in the production of toxic metabolites, which can injure enterocytes, increase intestinal permeability, and ultimately lead to systemic inflammation (Bures et al., 2010; Bowe and Logan, 2011; Bowe et al., 2014).

\section{Atopic Dermatitis}

Atopic dermatitis is the most common chronic pruritic inflammatory dermatosis, affecting $15-30 \%$ of children and $2-$ $10 \%$ of adults (Simpson et al., 2014; Seite and Bieber, 2015; Bin and Leung, 2016). It is a heterogeneous disorder with a variety of endotypes and phenotypes illustrated by wide variations in clinical features with respect to age, severity, and allergen response (Seite and Bieber, 2015; Bin and Leung, 2016; Irvine et al., 2016; Muraro et al., 2016; Huang et al., 2017).

Over the last few decades, our understanding of the pathogenesis of $\mathrm{AD}$ has improved with the discovery of more innate and adaptive immune cells and cytokines (Otsuka et al., 2017). Skin barrier dysfunction and altered immune responses are primary players in the pathogenesis of $\mathrm{AD}$ (Seite and Bieber, 2015; Bin and Leung, 2016; Irvine et al., 2016; Muraro et al., 2016; Huang et al., 2017). A compromised barrier secondary to environmental or genetic causes is typically the preceding event in $\mathrm{AD}$ development. The principal inherited cause of barrier dysfunction is loss of function mutations in the gene encoding FLG. FLG plays an essential role in maintaining epidermal homeostasis by assisting with water retention and barrier function. Therefore, a mutation in FLG results in 
increased TEWL as well as increased susceptibility to invasion by environmental antigens (Kelleher et al., 2015; Horimukai et al., 2016).

In the acute stage, allergens breaching a dysfunctional skin barrier will trigger the release of keratinocyte-derived cytokines such as TSLP, IL-33 and IL-25. IL-25 and IL-33 will in-turn activate type 2 innate lymphoid cells through their interaction with IL-17B and IL-1RL1, respectively, resulting in the production of IL-13 and IL-5 which will then stimulate a Th2 immune response. Activation of Th2 cells is further enhanced by TSLP-mediated maturation of Langerhans cells and CD11 ${ }^{+}$ dendritic cells. In the chronic stage, IL-22 released from Th22 CELLS promotes the epidermal production of anti-microbial peptides, including defensins, which can participate in skewing the immune response toward a more predominant Th1 response. Tissue remodeling seen in this stage could be secondary to an IL17 mediated release of pro-fibrotic cytokines such as IL-11 and TGF- $\beta$ from eosinophils (Otsuka et al., 2017).

Allergic diseases including asthma, hay fever, and eczema have increased in prevalence over the past several decades (Wesemann and Nagler, 2016; Johnson and Ownby, 2017). As developed countries known for their sterile environments saw the most dramatic rise in $\mathrm{AD}$ and other allergic diseases, the hygiene hypothesis, first proposed by Strachan (1989), was a widely accepted theory used to explain this phenomenon. Dr. Strachan proposed that allergic disorders arise when our immune system inappropriately responds to harmless antigens via Th2mediated responses. According to his hypothesis, early exposure to microbial antigens is essential to immune development, as it encourages Th1 rather than Th2-mediated immune responses. With more sterile environments in developed countries, the hygiene hypothesis explains the disproportionate rise of allergic disease in the western world. This theory, however, is flawed in that it fails to explain the parallel increase in prevalence of Th1-mediated autoimmune diseases. Another proposed explanation, the diet-microbiome theory, seeks to reconcile this flaw.

The diet-microbiome theory implies that the increased prevalence of allergic disease stems from a less robust state of immune homeostasis rather than from overresponse to innocuous environmental cues (Kim et al., 2013; Purchiaroni et al., 2013; Song et al., 2016; Johnson and Ownby, 2017). According to this theory, the gut microbiome's contribution to immune homeostasis is impaired by the typical western diet. Immune homeostasis begins to take shape early in life through exposure to maternal microbiota, and the infant's intestinal flora is further developed with exposure to breast milk, other food, and environmental microbes (Sironi and Clerici, 2010; Neu and Rushing, 2011; Clemente et al., 2012; Frei et al., 2012; Rook, 2012; Bendiks and Kopp, 2013; Kim et al., 2013; Purchiaroni et al., 2013; Bloomfield et al., 2016; Song et al., 2016; Johnson and Ownby, 2017). The low fiber and high fat content characteristic of the western diet fundamentally changes the gut microbiome, resulting in deficient production of immunomodulatory metabolites, particularly SCFAs. SCFAs are known for their anti-inflammatory actions mediated by G-protein coupled receptor 43 and for their contribution to epithelial barrier integrity (Maslowski et al., 2009). Antiinflammatory activity is further mediated by regulatory $\mathrm{T}$ cells and driven by TGF- $\beta$ and/or interleukin 10 (IL-10). IL-10 exerts its inhibitory function by inducing TGF- $\beta$ and other cytokines as well as suppressive signaling molecules including CTLA-4 and PD-1. Reduced local and systemic immune tolerance resulting from an altered gut microbiome may help explain the observed rise of both autoimmune and atopic disease observed in the western world (Maslowski et al., 2009; Agrawal et al., 2011; Purchiaroni et al., 2013; Seite and Bieber, 2015; Johnson and Ownby, 2017).

Studies have sought to demonstrate the link between intestinal dysbiosis and atopic disease (Johnson and Ownby, 2017). In two Korean studies, metagenomic analysis of fecal samples from patients with $\mathrm{AD}$ demonstrated a significant reduction in Faecalibacterium prausnitzii species compared to control patients. A parallel decrease in SCFA production among AD patients was observed as well. The authors emphasized a possible positive feedback loop between intestinal dysbiosis regarding F. prausnitzii and epithelial barrier disruption secondary to uncontrolled epithelial inflammation (Kim et al., 2013; Song et al., 2016). Disruption in the intestinal barrier contributes to this feedback loop by allowing the penetration of poorly digested food, microbes, and toxins into the circulation to reach target tissue, including the skin, where they trigger Th2 immune responses resulting in further tissue damage (Purchiaroni et al., 2013; Seite and Bieber, 2015; Song et al., 2016; Johnson and Ownby, 2017).

\section{Psoriasis}

Psoriasis is an immune-mediated chronic relapsing-remitting inflammatory dermatosis triggered by a multitude of environmental and internal factors in genetically susceptible individuals (Parisi et al., 2013; Rachakonda et al., 2014; Kulig et al., 2016; Takeshita et al., 2017). Histologic features include acanthosis, reflective of a state of keratinocyte hyperproliferation, and parakeratosis, indicative of dysregulated keratinocyte differentiation. Increased vascularity is characteristic as well, allowing for the accumulation of inflammatory subpopulations of neutrophils, dendritic cells, and T lymphocytes (Roberson and Bowcock, 2010; Kulig et al., 2016). Clinically, psoriasis commonly presents as recurrent episodes of well-demarcated scaly erythematous plaques but can rarely also manifest as generalized life-threatening erythroderma (Mari et al., 2017).

Treatment options have evolved as the pathophysiology of psoriasis has become better understood. Initially considered merely a hyperproliferative skin disorder, treatment once focused on anti-proliferative therapeutic modalities. In the 1980s, the Th1 subset of effector $\mathrm{T}$ cells their derived cytokines became the target of many psoriasis therapeutics. More recently, after the discovery of elevated IL-17 levels in psoriatic lesions, therapies have focused on Th17 cells, a novel subset of $\mathrm{T}$ cells, as a principal player. Th17 cytokines enhance the expression of the IL10 cytokine family including; IL-20 and IL-22 cytokines capable of promoting the hyperproliferation of keratinocytes. Following the discovery of the Th17 pathway, most clinical and mechanistic 
evidence suggests that psoriasis is primarily driven by the IL23/IL-17/Th17 axis (Baba et al., 2006; Fitch et al., 2007; GuttmanYassky et al., 2008; Ma et al., 2008; Gaffen et al., 2015; Coates et al., 2016).

Psoriasis is commonly accompanied by inflammation in other organ systems. Seven to $11 \%$ of inflammatory bowel disease (IBD) patients are diagnosed with psoriasis, making the association with GI inflammation particularly strong (Huang et al., 2012; Eppinga et al., 2014; Takeshita et al., 2017). Certain shared genetic and environmental factors as well as immune pathways have been implicated in the etiopathogenesis of both diseases (Huang et al., 2012). For example, Th17 cells and their cytokines, known to play a principal role in the development of psoriasis, have been implicated in the pathophysiology of IBD as well (Eppinga et al., 2014; Verstockt et al., 2016). This subset of cells is also thought to play a role in the development of ankylosing spondylitis and rheumatoid arthritis, two autoimmune inflammatory joint diseases commonly reported in patients with psoriasis and IBD (Zhang et al., 2012). Evidence such as this suggests another possible tri-directional axis orchestrated by the gut and its influence on the skin (Eppinga et al., 2014).

Metabolites produced by the intestinal microbiome have immune-modifying potential, capable of altering the balance between immune tolerance and inflammation through their influence on the differentiation of naïve $\mathrm{T}$ cells into either regulatory or Th17 lineages. Effector $\mathrm{T}$ cells are generally anabolic and depend on glycolysis as their source of adenosine triphosphate (ATP). Memory and resting T cells, however, are considered catabolic and utilize fatty acids and amino acids, in addition to glucose, to generate ATP through oxidative phosphorylation. The primary transcription factors of the lipogenic and glycolytic pathways are adenosine monophosphate activated kinase and rapamycin, respectively. Both serve as energy sensors and are regulated by the accessibility of nutrients in the gut milieu, which can be modulated by gut microbiota (Omenetti and Pizarro, 2015).

The pattern of dysbiosis found in IBD patients has also been described in psoriatic patients with and without IBD (Scher et al., 2015). There is depletion of symbiont bacteria, including Bifidobacteria, Lactobacilli, and Faecalibacterium prausnitzii as well as colonization with certain pathobionts such as Salmonella, Escherichia coli, Helicobacter, Campylobacter, Mycobacterium, and Alcaligenes. One study revealed a decreased presence of Parabacteroides and Coprobacillus, two beneficial gut species, in psoriasis and psoriatic arthritis patients comparable to what is observed in patients with IBD. Reduced presence of beneficial phyla may translate into functional consequences including poor regulation of intestinal immune responses that may then affect distant organ systems (Scher et al., 2015). F. prausnitzii, one of the most common microbial inhabitants of the large intestine, provides many benefits to the host. It serves as an important source of butyrate, a SCFA that provides energy for colonocytes, reduces oxidative stress, and imparts anti-inflammatory action by triggering regulatory $\mathrm{T}$ cells, thereby conferring immune tolerance that extends beyond the GI system (Sokol et al., 2008; Lopez-Siles et al., 2012). Psoriatic patients harbor a significantly lower number of this microbe compared to healthy controls (Eppinga et al., 2016). It has also been theorized that the far-reaching effects of intestinal dysbiosis are the result of gut microbes and their metabolites breaching an impaired intestinal barrier and entering systemic circulation to directly target distant organs, including the skin and joints. Consistent with this hypothesis, DNA of gut microbial origin has been isolated from the blood of patients with active psoriasis (Ramírez-Boscá et al., 2015).

\section{MODULATION OF THE GUT MICROBIOTA FOR TREATMENT AND PREVENTION (REHABILITATION OF THE GUT ECOSYSTEM)}

The gut microbiome is greatly influenced by diet. Though long-term dietary habits shape bacterial composition, dramatic modulation of diet over the short term can rapidly alter gut bacteria as well. Given the gut microbiome's influence on inflammatory disease, this provides an opportunity to intentionally modify the microbiome with therapeutic aims (Huang et al., 2017). Probiotic supplementation, the administration of live beneficial gut bacteria, has a promising potential role in the prevention and management of various skin conditions (Krutmann, 2009; Hill et al., 2014; Farris, 2016; Grant and Baker, 2017; Sánchez et al., 2017; Sarao and Arora, 2017). Prebiotics, non-viable bacterial components and metabolites, and synbiotics, the combination of pro- and prebiotics, offer similar health benefits (Muizzuddin et al., 2012; Frei et al., 2015).

\section{Cosmetic Effect of Probiotics on Skin}

Ultraviolet radiation is the primary external contributor to skin aging. Through its stimulation of signaling pathways which ultimately increase the transcription of target genes key to photoaging, UV radiation results in increased laxity, dryness, and pigmentation (Chen et al., 2015; Xia et al., 2015; Wiegand et al., 2016). Activator protein 1 is a matrix metalloproteinase (MMP) transcription factor with a primary role in UVB-induced skin aging. MMPs are zinc-dependent endopeptidases capable of degrading extracellular matrix macromolecules. Interstitial collagenase (MMP-1) cleaves collagen I and III fibrils in skin, while MMP-9 further degrades these fibrils into smaller peptides (Quan et al., 2013; Cavinato and Jansen-Dürr, 2017; Qin et al., 2017). MMP-2 and MMP-9, primarily expressed in the epidermis, break down collagen IV and VII found in the epidermal basement membrane (Pittayapruek et al., 2016). When keratinocytes are exposed to UVA radiation, there is increased expression of TNF$\alpha$, a pro-inflammatory cytokine (Jeong et al., 2016).

Studies have sought to demonstrate how modulation of the gut microbiome can influence immune signaling pathways in a way that counteracts UV damage. Lipoteichoic acid (LTA), a cell wall component of Lactobacillus species, is known for its anti-inflammatory properties (Jeong et al., 2016). In one Korean study, oral administration of Lactobacillus plantarum HY7714, resulted in the prevention of UV-induced photoaging 
in mice through the inhibition of MMP-1 expression in dermal fibroblasts (Kim H.M. et al., 2014). This anti-aging effect was reproduced in human research. In a double-blind, placebocontrolled study, oral supplementation of L. plantarum HY7714 in 110 middle-aged Korean subjects for 12 weeks resulted in improved cutaneous elasticity and increased skin hydration (Lee et al., 2015). Another study demonstrated that Lactobacillus sakei LTA is capable of reversing UV-induced skin aging through its immune modulating effect on monocytes (You et al., 2013).

\section{Probiotics and Acne Vulgaris}

Topical and oral antibiotics are often included in traditional acne treatment regimens. Though effective, this approach risks antibiotic resistance and disruption of the microbiome. Given the role of intestinal dysbiosis in inflammatory skin conditions, probiotic supplementation represents a promising alternate, or adjuvant, acne treatment approach.

In an early study of probiotic supplementation, the ingestion of Lactobacillus acidophilus and Lactobacillus bulgaricus probiotic tablets by 300 acne patients resulted in acne improvement in $80 \%$ of subjects, particularly in subjects with inflammatory lesions (Siver, 1961; Bowe and Logan, 2011; Bowe et al., 2014). Probiotics can suppress Propionibacterium acnes through the secretion of antibacterial protein. Streptococcus salivarius and Lactococcus HY449 produce bacteriocin-like inhibitory substance and bacteriocins, respectively, which inhibit the growth of P. acnes (Bowe and Logan, 2011; Bowe et al., 2014; Kober and Bowe, 2015). In another clinical study, subjects who received oral Lactobacillus and Bifidobacterium species in conjunction with oral antibiotics experienced a significantly greater decrease in acne lesion count compared to an antibioticonly control group (Table 2) (Volkova et al., 2001; Jung et al., 2013).

In addition to their antimicrobial effects, probiotics can disrupt the pathogenesis of acne through immunomodulatory and anti-inflammatory actions. In vitro studies of Streptococcus salivarius, a commensal microbe, attributed the antiinflammatory effect of this strain to inhibition of IL-8 secretion, suppression of the NF- $\mathrm{B}$ pathway, and downregulation of genes associated with the adhesion of bacteria to epidermal surfaces (Cosseau et al., 2008).

Probiotics may also lower the glycemic load, reduce IGF-1 signaling, and ultimately decrease keratinocyte proliferation and sebaceous gland hyperplasia. In one pilot study, the consumption of Lactobacillus rhamnosus SP1 for 12 weeks resulted in reduced expression of IGF-1 and oxidative stress markers (Table 2) (Fabbrocini et al., 2016). In a study of obese diabetic mice, administration of Bifidobacterium species resulted in inhibition of high-fat diet-induced endotoxemia and inflammation via a GLP-2-dependant mechanism. Increased glucagon-like peptide 2 (GLP-2), an intestinotrophic proglucagon-derived peptide, resulted in improved tight junction integrity and reduced intestinal permeability (Cani et al., 2009).

\section{Probiotics and Atopic Dermatitis}

The primary treatment approach to $\mathrm{AD}$ combines topical emollients and anti-inflammatory drugs to compensate for disrupted barrier function and poor immune tolerance, respectively (Muraro et al., 2016). Given the gut microbiome's integral role in immune development and homeostasis, probiotics may be useful in both the prevention and treatment of allergic disorders including $\mathrm{AD}$ via microbial, epithelial, and immune effects. Probiotics modify microbial composition, prevent pathogen invasion by competitively binding to epithelial cells, and suppress growth of pathogens by secreting bacteriocin. They also contribute to the restoration of impaired barrier function by increasing the expression of tight junction proteins as well as the production of SCFAs. Immune benefits include the inhibition of proinflammatory cytokines (IL-4, INF $\gamma$, IL-17) and the promotion of anti-inflammatory cytokines (IL-10, TGF- $\beta$ ). Probiotics can increase the number of regulatory $\mathrm{T}$ cells that suppress the cutaneous expression of thymic stromal lymphopoietin involved in the stimulation of dendritic cells, effectively preventing the differentiation of naïve $\mathrm{T}$ cells into Th2 and Th17 subtypes. Regulatory $\mathrm{T}$ cells can migrate to the skin and inhibit Th2 and Th17 responses, thereby exerting a therapeutic role in addition to a preventative one (Kim et al., 2013; Chang et al., 2016; McCusker and Sidbury, 2016; Rather et al., 2016).

Lactobacillus and Bifidobacterium species are the most commonly tested probiotics in AD (Kim et al., 2010; Enomoto et al., 2014). Oral supplementation with Lactobacillus rhamnosus Lcr35 in an $\mathrm{AD}$ mouse model resulted in the upregulation of CD4+CD25+Foxp3+ regulatory T cells and the downregulation of interleukin-4 and thymic stromal lymphopoietin (Table 1) (Kim et al., 2012). In a separate study, supplementation of another AD mouse model with Lactobacillus plantarum CJLP55, CJLP133, and CJLP136 resulted in inhibition of house dust mite-induced dermatitis via increased production of IL-10 and alteration of the Th1/Th2 balance (Won et al., 2011). After supplementation with Lactobacillus rhamnosus IDCC 3201, there was suppression of mast cell mediated inflammation in the same mouse model (Lee et al., 2016).

In humans, prenatal and postnatal probiotics have proven efficacy in the management, and even prevention, of AD in high risk infants. In one placebo-controlled study, Bifidobacterium bifidum BGN4, Bifidobacterium lactis AD011, and Lactobacillus acidophilus AD031 supplements were given to pregnant Korean women with a positive family history of AD 4-8 weeks before delivery and to their infants for the first 2 months of life. The incidence of AD was significantly lower in the probiotictreated group compared to the control group (Kim et al., 2010). In a separate study, prenatal and postnatal probiotic milk supplementation in Norwegian women and their infants was also associated with a reduced incidence of AD (Bertelsen et al., 2014). In a third study, maternal and infant supplementation with Bifidobacterium breve M-16V and Bifidobacterium longum BB536 further supported the preventative effect of probiotics in $\mathrm{AD}$ (Enomoto et al., 2014). Regarding AD treatment, a recent metaanalysis was conducted of studies investigating the efficacy of probiotics in $\mathrm{AD}$ symptom-control. This analysis concluded that probiotic use improved $\mathrm{AD}$, reflected by a significant reduction in the Severity Scoring of $\mathrm{AD}$ index, in all ages except infants under 1 year (Chang et al., 2016). 


\section{Probiotics and Psoriasis}

Data on probiotic supplementation in psoriasis treatment are limited, but promising outcomes have been documented. One study evaluating the effect of Lactobacillus pentosus GMNL-77 on an imiquimod-induced psoriasis mouse model found that probiotic-treated mice experienced significantly less erythema, scaling, and epidermal thickening compared to untreated control mice (Chen et al., 2017). Oral administration of L. pentosus GMNL-77 appeared to suppress expression of TNF- $\alpha$, IL-6, and proinflammatory cytokines in the IL-23/IL-17 cytokine axis. Though the mechanism for reduced $\mathrm{T}$ cell activity was unclear, the study authors proposed that this effect was mediated by suppression of CD103+ dendritic cells, intestinal antigen presenting cells that have been shown to modulate regulatory $\mathrm{T}$ cells in the GI tract. In a separate placebocontrolled study of psoriasis patients, Bifidobacterium infantis 35624 supplementation led to significantly reduced plasma levels of TNF- $\alpha$ in the probiotic-treated group (Table 2) (Groeger et al., 2013). In one documented case of severe pustular psoriasis unresponsive to steroids, dapsone, and methotrexate, clinical improvement was observed within 2 weeks of initiating Lactobacillus sporogenes supplementation three times per day, with almost complete resolution achieved at 4 weeks (Vijayashankar and Raghunath, 2012).

\section{CONCLUSION AND FUTURE PERSPECTIVES}

Basic science research and clinical studies have demonstrated the gut microbiome's contribution to host homeostasis, allostasis,

\section{REFERENCES}

Abhishek, S., Tech, M., and Krishnan, S. P. (2016). Epidermal differentiation complex: a review on its epigenetic regulation and potential drug targets. Cell J. 18, 1-6. doi: 10.22074/cellj.2016.3980

Agak, G. W., Qin, M., Nobe, J., Kim, M., Krutzik, S. R., Tristan, G. R., et al. (2014). Propionibacterium acnes induces an IL-17 response in acne vulgaris that is regulated by vitamin A and vitamin D. J. Invest. Dermatol. 134, 366-373. doi: $10.1038 /$ jid.2013.334

Agamia, N. F., Abdallah, D. M., Sorour, O., Mourad, B., and Younan, D. N. (2016). Skin expression of mammalian target of rapamycin and forkhead box transcription factor O1, and serum insulin-like growth factor-1 in patients with acne vulgaris and their relationship with diet. Br. J. Dermatol. 174, 1299-1307. doi: $10.1111 /$ bjd.14409

Agrawal, R., Wisniewski, J. A., and Woodfolk, J. A. (2011). "The role of regulatory $\mathrm{T}$ cells in atopic dermatitis," in Pathogenesis and Management of Atopic Dermatitis, Vol. 41, ed. T. Shiohara (Basel: Karger Publishers), 112-124.

Arck, P., Handjiski, B., Hagen, E., Pincus, M., Bruenahl, C., Bienenstock, J., et al. (2010). Is there a 'gut-brain-skin axis'? Exp. Dermatol. 19, 401-405. doi: 10. 1111/j.1600-0625.2009.01060.x

Baba, H., Masuyama, A., and Takano, T. (2006). Short communication: effects of Lactobacillus helveticus-fermented milk on the differentiation of cultured normal human epidermal keratinocytes. J. Dairy Sci. 89, 2072-2075. doi: 10. 3168/jds.S0022-0302(06)72275-5

Baba, H., Masuyama, A., and Yoshimura, C. (2012). Promoter of differentiation and keratinization of epidermic cell and functional beverage/food for promotion of keratinization of epidermis. U.S. Patent NO CA2614111A1.

Baba, H., Masuyama, A., Yoshimura, C., Aoyama, Y., Takano, T., and Ohki, K. (2010). Oral intake of Lactobacillus helveticus-fermented milk whey decreased and the pathogenesis of disease. Through complex immune mechanisms, the influence of the gut microbiome extends to involve distant organ systems including the skin. With intentional modulation of the microbiome, probiotics, prebiotics, and synbiotics have proven beneficial in the prevention and/or treatment of inflammatory skin diseases including acne vulgaris, $\mathrm{AD}$, and psoriasis. In this up-and-coming field, future research should improve our understanding of the complex mechanisms underlying the gut-skin axis, investigate the therapeutic potential of long-term modulation of the gut microbiome, and potentially expand therapeutic manipulation to include commensal gut fungi and viruses in order to fully harness the gut microbiome's influence in the treatment of skin disease.

\section{AUTHOR CONTRIBUTIONS}

IS and AR were responsible for data research and collation; NI for manuscript review, and $\mathrm{MG}$ for overall review.

\section{ACKNOWLEDGMENTS}

The authors would like to thank Thomas S. McCormick, Ph.D., Associate professor, Department of Dermatology, and Wendy Goodman, Ph.D., Instructor, Department of Pathology, Case Western Reserve University, Cleveland, $\mathrm{OH}$, United States, for their assistance with manuscript editing.

transepidermal water loss and prevented the onset of sodium dodecylsulfateinduced dermatitis in mice. Biosci. Biotechnol. Biochem. 74, 18-23. doi: 10.1271/ bbb. 90370

Bendiks, M., and Kopp, M. V. (2013). The relationship between advances in understanding the microbiome and the maturing hygiene hypothesis. Curr. Allergy Asthma Rep. 13, 487-494. doi: 10.1007/s11882-013-0382-8

Benyacoub, J., Bosco, N., Blanchard, C., Demont, A., Philippe, D., CastielHigounenc, I., et al. (2014). Immune modulation property of Lactobacillus paracasei NCC2461 (ST11) strain and impact on skin defences. Benef. Microbes 5, 129-136. doi: 10.3920/BM2013.0014

Bercik, P., and Collins, S. M. (2014). "The effects of inflammation, infection and antibiotics on the microbiota-gut-brain axis," in Microbial Endocrinology: the Microbiota-Gut-Brain Axis in Health and Disease. Advances in Experimental Medicine and Biology, Vol. 817, eds M. Lyte and J. Cryan (New York, NY: springer).

Bertelsen, R. J., Brantsæter, A. L., Magnus, M. C., Haugen, M., Myhre, R., Jacobsson, B., et al. (2014). Probiotic milk consumption in pregnancy and infancy and subsequent childhood allergic diseases. J. Allergy Clin. Immunol. 133, 165-171. doi: 10.1016/j.jaci.2013.07.032

Bhate, K., and Williams, H. C. (2013). Epidemiology of acne vulgaris. Br. J. Dermatol. 168, 474-485. doi: 10.1111/bjd.12149

Bik, E. M. (2009). Composition and function of the human-associated microbiota. Nutr. Rev. 67(Suppl. 2), S164-S171. doi: 10.1111/j.1753-4887.2009. 00237.x

Bin, L., and Leung, D. Y. M. (2016). Genetic and epigenetic studies of atopic dermatitis. Allergy Asthma Clin. Immunol. 12:52. doi: 10.1186/s13223-0160158-5

Bloomfield, S. F., Rook, G. A. W., Scott, E. A., Shanahan, F., Stanwell-Smith, R., and Turner, P. (2016). Time to abandon the hygiene hypothesis: new perspectives 
on allergic disease, the human microbiome, infectious disease prevention and the role of targeted hygiene. Perspect Public Health 136, 213-224. doi: 10.1177/ 1757913916650225

Borovaya, A., Dombrowski, Y., Zwicker, S., Olisova, O., Ruzicka, T., Wolf, R., et al. (2014). Isotretinoin therapy changes the expression of antimicrobial peptides in acne vulgaris. Arch. Dermatol. Res. 306, 689-700. doi: 10.1007/s00403-0141477-3

Bowe, W., Patel, N. B., and Logan, A. C. (2014). Acne vulgaris, probiotics and the gut-brain-skin axis: from anecdote to translational medicine. Benef. Microbes 5 , 185-199. doi: 10.3920/BM2012.0060

Bowe, W. P., and Logan, A. C. (2011). Acne vulgaris, probiotics and the gut-brain-skin axis-back to the future? Gut Pathog. 3:1. doi: 10.1186/17574749-3-1

Bowe, W. P., Patel, N., and Logan, A. C. (2012). Acne vulgaris: the role of oxidative stress and the potential therapeutic value of local and systemic antioxidants. J. Drugs Dermatol. 11, 742-746.

Boyle, R. J., Lahtinen, S. J., and Tang, M. L. K. (2011). "Probiotics and skin," in Nutrition and Skin, ed. A. Pappas (New York, NY: springer).

Branchet-Gumila, M. C., Boisnic, S., Le Charpentier, Y., Nonotte, I., Montastier, C., and Breton, L. (1999). Neurogenic modifications induced by substance P in an organ culture of human skin. Skin Pharmacol. Physiol. 12, 211-220. doi: 10.1159/000066245

Bures, J., Cyrany, J., Kohoutova, D., Förstl, M., Rejchrt, S., Kvetina, J., et al. (2010). Small intestinal bacterial overgrowth syndrome. World J. Gastroenterol. 16, 2978-2990. doi: 10.3748/wjg.v16.i24.2978

Cani, P. D., Possemiers, S., Van de Wiele, T., Guiot, Y., Everard, A., Rottier, O., et al. (2009). Changes in gut microbiota control inflammation in obese mice through a mechanism involving GLP-2-driven improvement of gut permeability. Gut 58, 1091-1103. doi: 10.1136/gut.2008.165886

Cavinato, M., and Jansen-Dürr, P. (2017). Molecular mechanisms of UVB-induced senescence of dermal fibroblasts and its relevance for photoaging of the human skin. Exp. Gerontol. 94, 78-92. doi: 10.1016/j.exger.2017.01.009

Chang, Y., Trivedi, M. K., Jha, A., Lin, Y., Dimaano, L., and García-Romero, M. T. (2016). Synbiotics for prevention and treatment of atopic dermatitis: a meta-analysis of randomized clinical trials. JAMA Pediatr. 170, 236-242. doi: 10.1001/jamapediatrics.2015.3943

Chapat, L., Chemin, K., Dubois, B., Bourdet-Sicard, R., and Kaiserlian, D. (2004). Lactobacillus casei reduces CD8 + T cell-mediated skin inflammation. Eur. J. Immunol. 34, 2520-2528. doi: 10.1002/eji.200425139

Chen, B., Li, R., Yan, N., Chen, G., Qian, W., Jiang, H., et al. (2015). Astragaloside IV controls collagen reduction in photoaging skin by improving transforming growth factor- $\beta /$ Smad signaling suppression and inhibiting matrix metalloproteinase-1. Mol. Med. Rep. 11, 3344-3348. doi: 10.3892/mmr. 2015.3212

Chen, Y., Wu, C., Chao, Y., Lin, C., Tsai, H., Li, Y., et al. (2017). Lactobacillus pentosus GMNL-77 inhibits skin lesions in imiquimod-induced psoriasis-like mice. J. Food Drug Anal. 25, 559-566. doi: 10.1016/j.jfda.2016. 06.003

Clarke, T. B., Davis, K. M., Lysenko, E. S., Zhou, A. Y., Yu, Y., and Weiser, J. N. (2010). Recognition of peptidoglycan from the microbiota by Nod1 enhances systemic innate immunity. Nat. Med. 16, 228-231. doi: 10.1038/nm.2087

Clemente, J. C., Ursell, L. K., Parfrey, L. W., and Knight, R. (2012). The impact of the gut microbiota on human health: an integrative view. Cell 148, 1258-1270. doi: $10.1016 /$ j.cell.2012.01.035

Coates, L., Savage, L., and Emery, P. (2016). "Pathogenesis of psoriasis and psoriatic arthritis," in Handbook of Psoriasis and Psoriatic Arthritis, eds R. Warren and A. Menter (Cham: adis).

Cosseau, C., Devine, D. A., Dullaghan, E., Gardy, J. L., Chikatamarla, A., Gellatly, S., et al. (2008). The commensal Streptococcus salivarius K12 downregulates the innate immune responses of human epithelial cells and promotes host-microbe homeostasis. Infect. Immun. 76, 4163-4175. doi: 10.1128/IAI.00188-08

Dawson, A. L., and Dellavalle, R. P. (2013). Acne vulgaris. BMJ 346:f2634. doi: 10.1136/bmj.f2634

Dawson, L. F., Donahue, E. H., Cartman, S. T., Barton, R. H., Bundy, J., McNerney, R., et al. (2011). The analysis of para-cresol production and tolerance in Clostridium difficile 027 and 012 strains. BMC Microbiol. 11:86. doi: 10.1186/1471-2180-11-86
Do, J. E., Cho, S., In, S., Lim, K., Lee, S., and Lee, E. (2009). Psychosocial aspects of acne vulgaris: a community-based study with Korean adolescents. Ann. Dermatol. 21, 125-129. doi: 10.5021/ad.2009.21.2.125

Dougan, S. K., Kaser, A., and Blumberg, R. S. (2007). "CD1 expression on antigenpresenting cells," in T Cell Activation by CD1 and Lipid Antigens. Current Topics in Microbiology and Immunology, Vol. 314, ed. D. B. Moody (Berlin: springer), doi: 10.1007/978-3-540-69511-0_5

Dreno, B., Martin, R., Moyal, D., Henley, J. B., Khammari, A., and Seite, S. (2017). Skin microbiome and acne vulgaris: staphylococcus, a new actor in acne. Exp. Dermatol. 26, 798-803. doi: 10.1111/exd.13296

Duman, H., Topal, I. O., Kocaturk, E., and Duman, M. A. (2016). Evaluation of anxiety, depression, and quality of life in patients with acne vulgaris, and quality of life in their families. DSI 34, 6-9. doi: 10.1016/j.dsi.2015.07.002

Enomoto, T., Sowa, M., Nishimori, K., Shimazu, S., Yoshida, A., Yamada, K., et al. (2014). Effects of bifidobacterial supplementation to pregnant women and infants in the prevention of allergy development in infants and on fecal microbiota. Allergol. Int. 63, 575-585. doi: 10.2332/allergolint.13-OA-0683

Eppinga, H., Konstantinov, S. R., Peppelenbosch, M. P., and Thio, H. B. (2014). The microbiome and psoriatic arthritis. Curr. Rheumatol. Rep. 16, 1-8. doi: 10.1007/s11926-013-0407-2

Eppinga, H., Weiland, C. J. S., Thio, H. B., van der Woude, C. J., Nijsten, T. E. C., Peppelenbosch, M. P., et al. (2016). Similar depletion of protective Faecalibacterium prausnitzii in psoriasis and inflammatory bowel disease, but not in hidradenitis suppurativa. J. Crohns. Colitis 10, 1067-1075. doi: 10.1093/ ecco-jcc/jjw070

Esplugues, E., Huber, S., Gagliani, N., Hauser, A. E., Town, T., Wan, Y. Y., et al. (2011). Control of TH17 cells occurs in the small intestine. Nature 475, 514-518. doi: 10.1038/nature 10228

Fabbrocini, G., Bertona, M., Picazo, Ó., Pareja-Galeano, H., Monfrecola, G., and Emanuele, E. (2016). Supplementation with Lactobacillus rhamnosus SP1 normalises skin expression of genes implicated in insulin signalling and improves adult acne. Benef. Microbes 7, 625-630. doi: 10.3920/BM2016.0089

Farris, P. K. (2016). Are skincare Products with probiotics worth the hype?. Dermatology Times, 8th, August.

Fitch, E., Harper, E., Skorcheva, I., Kurtz, S. E., and Blauvelt, A. (2007). Pathophysiology of psoriasis: recent advances on IL-23 and Th17 cytokines. Curr. Rheum. Rep. 9, 461-467. doi: 10.1007/s11926-007-0075-1

Forbes, J. D., Van Domselaar, G., and Bernstein, C. N. (2015). The gut microbiota in immune-mediated inflammatory diseases. Front. Microbiol. 7:1081.

Fox, L., Csongradi, C., Aucamp, M., du Plessis, J., and Gerber, M. (2016). Treatment modalities for acne. Molecules 21:1063. doi: 10.3390/molecules 21081063

Frei, R., Akdis, M., and O’Mahony, L. (2015). Prebiotics, probiotics, synbiotics, and the immune system: experimental data and clinical evidence. Curr. Opin. Gastroenterol. 31, 153-158. doi: 10.1097/MOG.00000000000 00151

Frei, R., Lauener, R. P., Crameri, R., and O’Mahony, L. (2012). Microbiota and dietary interactions: an update to the hygiene hypothesis? Allergy 67, 451-461. doi: 10.1111/j.1398-9995.2011.02783.x

Gaffen, S. L., Jain, R., Garg, A. V., and Cua, D. J. (2015). IL-23-IL-17 immune axis: discovery, mechanistic understanding, and clinical testing. Nat. Rev. Immunol. 14, 585-600. doi: 10.1038/nri3707

Gaur, M., Dobke, M., and Lunyak, V. V. (2014). Mesenchymal stem cells from adipose tissue in clinical applications for dermatological indications and skin aging. Int. J. Mol. Sci. 18:208. doi: 10.3390/ijms18010208

Gloster, H. M., Gebauer, L. E., and Mistur, R. L. (2016). “Cutaneous manifestations of gastrointestinal disease," in Absolute Dermatology Review, eds H. M. Gloster, L. E. Gebauer, and R. L. Mistur (Cham: springer), doi: 10.1007/978-3-31903218-4_48

Grant, M. C., and Baker, J. S. (2017). An overview of the effect of probiotics and exercise on mood and associated health conditions. Crit. Rev. Food Sci. Nutr. 57, 3887-3893. doi: 10.1080/10408398.2016.1189872

Groeger, D., O’Mahony, L., Murphy, E. F., Bourke, J. F., Dinan, T. G., Kiely, B., et al. (2013). Bifidobacterium infantis 35624 modulates host inflammatory processes beyond the gut. Gut Microbes 4, 325-339. doi: 10.4161/gmic.25487

Guéniche, A., Philippe, D., Bastien, P., Reuteler, G., Blum, S., Castiel-Higounenc, I., et al. (2013). Randomised double-blind placebo-controlled study of the effect of Lactobacillus paracasei NCC 2461 on skin reactivity. Benef. Microbes 5, 137-145. doi: 10.3920/BM2013.0001 
Guéniche, A. G., Benyacoub, J., Buetler, T. M., Smola, H., and Blum, S. (2006). Supplementation with oral probiotic bacteria maintains cutaneous immune homeostasis after UV exposure. Eur. J. Dermatol. 16, 511-517. doi: 10.1684/ ejd.2006.0023

Guéniche, A. G., Benyacoub, J., Philippe, D., Bastien, P., Kusy, N., Breton, L., et al. (2010). Lactobacillus paracasei CNCM I-2116 (ST11) inhibits substance P-induced skin inflammation and accelerates skin barrier function recovery in vitro. Eur. J. Dermatol. 20, 731-737. doi: 10.1684/ejd.2010. 1108

Guttman-Yassky, E., Lowes, M. A., Fuentes-Duculan, J., Zaba, L. C., Cardinale, I., Nograles, K. E., et al. (2008). Low expression of the IL-23/Th17 pathway in atopic dermatitis compared to psoriasis. J. Immunol. 181, 7420-7427. doi: 10.4049/jimmunol.181.10.7420

Hacini-Rachinel, F., Gheit, H., Le Luduec, J. B., Dif, F., Nancey, S., and Kaiserlian, D. (2009). Oral probiotic control skin inflammation by acting on both effector and regulatory T cells. PLoS One 4:e4903. doi: 10.1371/journal. pone.0004903

Hay, R. J., Johns, N. E., Williams, H. C., Bolliger, I. W., Dellavalle, R. P., Margolis, D. J., et al. (2014). The global burden of skin disease in 2010: an analysis of the prevalence and impact of skin conditions. J. Invest. Dermatol. 134, 1527-1534. doi: 10.1038/jid.2013.446

Hill, C., Guarner, F., Reid, G., Gibson, G. R., Merenstein, D. J., Pot, B., et al. (2014). Expert consensus document: the International Scientific Association for Probiotics and Prebiotics consensus statement on the scope and appropriate use of the term probiotic. Nat. Rev. Gastroenterol. Hepatol. 11, 506-514. doi: 10.1038/nrgastro.2014.66

Horii, Y., Kaneda, H., Fujisaki, Y., Fuyuki, R., Nakakita, Y., Shigyo, T., et al. (2014). Effect of heat-killed Lactobacillus brevis SBC8803 on cutaneous arterial sympathetic nerve activity, cutaneous blood flow and transepidermal water loss in rats. J. Appl. Microbiol. 116, 1274-1281. doi: 10.1111/jam.12435

Horimukai, K., Morita, K., Narita, M., Kondo, M., Kabashima, S., Inoue, E., et al. (2016). Transepidermal water loss measurement during infancy can predict the subsequent development of atopic dermatitis regardless of filaggrin mutations. Allergol. Int. 65, 103-108. doi: 10.1016/j.alit.2015.09.004

Huang, B. L., Chandra, S., and Shih, D. Q. (2012). Skin manifestations of inflammatory bowel disease. Front. Physiol. 3:13. doi: 10.3389/fphys.2012.00013

Huang, Y. J., Marsland, B. J., Bunyavanich, S., O’Mahoney, L., Leung, D. Y. M., Muraro, A., et al. (2017). The microbiome in allergic disease: current understanding and future opportunities - 2017 PRACTALL document of the American Academy of Allergy, Asthma \& Immunology and the European Academy of Allergy and Clinical Immunology. J. Allergy Clin. Immunol. 139, 1099-1110. doi: 10.1016/j.jaci.2017.02.007

Ipci, K., Altıntoprak, N., Muluk, N. B., Senturk, M., and Cingi, C. (2017). The possible mechanisms of the human microbiome in allergic diseases. Eur. Arch. Otorhinolaryngol. 274, 1-10. doi: 10.1007/s00405-016-4058-6

Irvine, A. D., Simpson, E. L., Eichenfield, L. F., and Friedlander, S. F. (2016). Review of critical issues in the pathogenesis of atopic dermatitis. Semin. Cutan Med. Surg. 35, S89-S91. doi: 10.12788/j.sder.2016.042

Jena, A. K., and Sahoo, S. (2016). Evaluation of associated anxiety and depression in patients with acne vulgaris: a hospital based clinico-epidemiological study. PIJR 5:10. doi: 10.15373/22501991

Jeong, J. H., Lee, C. Y., and Chung, D. K. (2016). Probiotic lactic acid bacteria and skin health. Crit. Rev. Food Sci. Nutr. 56, 2331-2337. doi: 10.1080/10408398. 2013.834874

Johnson, C. C., and Ownby, D. R. (2017). The infant gut bacterial microbiota and risk of pediatric asthma and allergic diseases. Transl. Res. 179, 60-70. doi: $10.1016 /$ j.trsl.2016.06.010

Jung, G. W., Tse, J. E., Guiha, I., and Rao, J. (2013). Prospective, randomized, openlabel trial comparing the safety, efficacy, and tolerability of an acne treatment regimen with and without a probiotic supplement and minocycline in subjects with mild to moderate acne. J. Cutan Med. Surg. 17, 114-122. doi: 10.2310/7750. 2012.12026

Katzman, M., and Logan, A. C. (2007). Acne vulgaris: nutritional factors may be influencing psychological sequelae. Med. Hypotheses. 69, 1080-1084. doi: 10.1016/j.mehy.2007.02.037

Kelleher, M., Dunn-Galvin, A., Hourihane, J. O., Murray, D., Campbell, L. E., McLean, W. H. I., et al. (2015). Skin barrier dysfunction measured by transepidermal water loss at 2 days and 2 months predates and predicts atopic dermatitis at 1 year. J. Allergy Clin. Immunol. 135, 930-935. doi: 10.1016/j.jaci. 2014.12.013

Kim, H., Kim, H. Y., Lee, S., Seo, J., Lee, E., and Hong, S. (2013). Clinical efficacy and mechanism of probiotics in allergic diseases. Korean J. Pediatr. 56, 369-376. doi: $10.3345 / \mathrm{kjp} .2013 .56 .9 .369$

Kim, H., Kim, Y., Kang, M., Seo, J., Kim, H., Jeong, S., et al. (2012). A novel mouse model of atopic dermatitis with epicutaneous allergen sensitization and the effect of Lactobacillus rhamnosus. Exp. Dermatol. 21, 672-675. doi: 10.1111/j. 1600-0625.2012.01539.x

Kim, H. M., Lee, D. E., Park, S. D., Kim, Y., Kim, Y. J., Jeong, J. W., et al. (2014). Oral administration of Lactobacillus plantarum HY7714 protects hairless mouse against ultraviolet B-induced photoaging. J. Microbiol. Biotechnol. 24, 1583-1591. doi: 10.4014/jmb.1406.06038

Kim, J. Y., Kwon, J. H., Ahn, S. H., Lee, S. I., Han, Y. S., Choi, Y. O., et al. (2010). Effect of probiotic mix (Bifidobacterium bifidum, Bifidobacterium lactis, Lactobacillus acidophilus) in the primary prevention of eczema: a double-blind, randomized, placebo-controlled trial. Pediatr. Allergy Immunol. 21, e386-93. doi: 10.1111/j.1399-3038.2009.00958.x

Kim, Y. G., Udayanga, K. G., Totsuka, N., Weinberg, J. B., Nuñez, G., and Shibuya, A. (2014). Gut dysbiosis promotes M2 macrophage polarization and allergic airway inflammation via fungi-induced PGE2. Cell Host Microbe 15, 95-102. doi: 10.1016/j.chom.2013.12.010

Kober, M. M., and Bowe, W. P. (2015). The effect of probiotics on immune regulation, acne, and photoaging. Int. J. Womens Dermatol. 1, 85-89. doi: 10.1016/j.ijwd.2015.02.001

Kosiewicz, M. M., Dryden, G. W., Chhabra, A., and Alard, P. (2014). Relationship between gut microbiota and development of $\mathrm{T}$ cell associated disease. FEBS Lett. 588, 4195-4206. doi: 10.1016/j.febslet.2014.03.019

Krutmann, J. (2009). Pre-and probiotics for human skin. J. Dermatol. Sci. 54, 1-5. doi: 10.1016/j.jdermsci.2009.01.002

Kulig, P., Musiol, S., Freiberger, S. N., Schreiner, B., Gyülveszi, G., Russo, G., et al. (2016). IL-12 protects from psoriasiform skin inflammation. Nat. Commun. 7:13466. doi: $10.1038 /$ ncomms 13466

Lee, D. E., Huh, C., Ra, J., Choi, I., Jeong, J., Kim, S., et al. (2015). Clinical evidence of effects of Lactobacillus plantarum HY7714 on skin aging: a randomized, double blind, placebo-controlled study. J. Microbiol. Biotechnol. 25, 2160-2168. doi: 10.4014/jmb.1509.09021

Lee, S., Yoon, J., Kim, Y., Jeong, D., Park, S., and Kang, D. (2016). Therapeutic effect of tyndallized Lactobacillus rhamnosus IDCC 3201 on atopic dermatitis mediated by down-regulation of immunoglobulin E in NC/Nga mice. Microbiol. Immunol. 60, 468-476. doi: 10.1111/1348-0421.12390

Lee, W. J., Jung, H. D., Lee, H. J., Kim, B. S., Lee, S., and Kim, D. W. (2008). Influence of substance-P on cultured sebocytes. Arch. Dermatol. Res. 300, 311-316. doi: 10.1007/s00403-008-0854-1

Levkovich, T., Poutahidis, T., Smillie, C., Varian, B. J., Ibrahim, Y. M., Lakritz, J. R., et al. (2013). Probiotic bacteria induce a 'glow of health'. PLoS One 8:e53867. doi: 10.1371/journal.pone.0053867

Lopez-Siles, M., Khan, T. M., Duncan, S. H., Harmsen, H. J. M., Garcia-Gil, L. J., and Flint, H. J. (2012). Cultured representatives of two major phylogroups of human colonic Faecalibacterium prausnitzii can utilize pectin, uronic acids, and host-derived substrates for growth. Appl. Environ. Microbiol. 78, 420-428. doi: 10.1128/AEM.06858-11

Loser, K., and Beissert, S. (2012). Regulatory T cells: banned cells for decades. J. Invest. Dermatol. 132, 864-871. doi: 10.1038/jid.2011.375

Lynn, D., Umari, T., Dunnick, C., and Dellavalle, R. (2016). The epidemiology of acne vulgaris in late adolescence. Adolesc. Health Med. Ther. 7, 13-25. doi: 10.2147/AHMT.S55832

Ma, H., Liang, S., Li, J., Napierata, L., Brown, T., Benoit, S., et al. (2008). IL-22 is required for Th17 cell-mediated pathology in a mouse model of psoriasis-like skin inflammation. J. Clin. Invest. 118, 597-607. doi: 10.1172/JCI33263

Macpherson, A. J., and Harris, N. L. (2004). Interactions between commensal intestinal bacteria and the immune system. Nat. Rev. Immunol. 4, 478-485. doi: $10.1038 /$ nri1373

Mari, N. L., Simão, A. N. C., and Dichi, I. (2017). n-3 polyunsaturated fatty acids supplementation in psoriasis: a review. Nutrire 42:5. doi: 10.1186/s41110-0160029-3

Maslowski, K. M., Vieira, A. T., Ng, A., Kranich, J., Sierro, F., Yu, D., et al. (2009). Regulation of inflammatory responses by gut microbiota and 
chemoattractant receptor GPR43. Nature 461, 1282-1286. doi: 10.1038/nature 08530

McCusker, M., and Sidbury, R. (2016). Nutrition and skin: kids are not just little people. Clin. Dermatol. 34, 698-709. doi: 10.1016/j.clindermatol.2016. 07.004

Meijer, K., de Vos, P., and Priebe, M. G. (2010). Butyrate and other short-chain fatty acids as modulators of immunity: what relevance for health? Curr. Opin. Clin. Nutr. Metab. Care 13, 715-721. doi: 10.1097/MCO.0b013e32833eebe5

Melnik, B. C. (2015). Milk. A nutrient system of mammalian evolution promoting mTORC1-dependent translation. Int. J. Mol. Sci. 16, 17048-17087. doi: 10.3390/ ijms 160817048

Miyazaki, K., Masuoka, N., Kano, M., and Iizuka, R. (2014). Bifidobacterium fermented milk and galacto-oligosaccharides lead to improved skin health by decreasing phenols production by gut microbiota. Benef. Microbes 5, 121-128. doi: 10.3920/BM2012.0066

Moore-Connors, J. M., Dunn, K. A., Bielawski, J. P., and Van Limbergen, J. (2016). Novel strategies for applied metagenomics. Inflamm. Bowel Dis. 22, 709-718. doi: 10.1097/MIB.0000000000000717

Muizzuddin, N., Maher, W., Sullivan, M., Schnittger, S., and Mammone, T. (2012). Physiological effect of a probiotic on skin. J. Cosmet. Sci. 63, 385-395.

Muraro, A., Lemanske, R. F., Hellings, P. W., Akdis, C. A., Bieber, T., Casale, T. B., et al. (2016). Precision medicine in patients with allergic diseases: airway diseases and atopic dermatitis-PRACTALL document of the European Academy of Allergy and Clinical Immunology and the American Academy of Allergy, Asthma \& Immunology. J. Allergy Clin. Immunol. 137, 1347-1358. doi: $10.1016 /$ j.jaci.2016.03.010

Neu, J., and Rushing, J. (2011). Cesarean versus vaginal delivery: long-term infant outcomes and the hygiene hypothesis. Clin. Perinatol. 38, 321-331. doi: 10.1016/j.clp.2011.03.008

Noureldein, M. H., and Eid, A. A. (2018). Gut microbiota and mTOR signaling: insight on a new pathophysiological interaction. Microb. Pathog. 118, 98-104. doi: 10.1016/j.micpath.2018.03.021

Ogawa, M., Saiki, A., Matsui, Y., Tsuchimoto, N., Nakakita, Y., Takata, Y., et al. (2016). Effects of oral intake of heat-killed Lactobacillus brevis SBC8803 $\left(\mathrm{SBL} 88^{\mathrm{TM}}\right)$ on dry skin conditions: a randomized, double-blind, placebocontrolled study. Exp. Ther. Med. 12, 3863-3872. doi: 10.3892/etm.2016.3862

Omenetti, S., and Pizarro, T. T. (2015). The Treg/Th17 axis: a dynamic balance regulated by the gut microbiome. Front. Immunol. 6:639. doi: 10.3389/fimmu. 2015.00639

O’Neill, C. A., Monteleone, G., McLaughlin, J. T., and Paus, R. (2016). The gut-skin axis in health and disease: a paradigm with therapeutic implications. Bioessays 38, 1167-1176. doi: 10.1002/bies.201600008

Otsuka, A., Nomura, T., Rerknimitr, P., Seidel, J. A., Honda, T., and Kabashima, K. (2017). The interplay between genetic and environmental factors in the pathogenesis of atopic dermatitis. Immunol. Rev. 278, 246-262. doi: 10.1111/ imr. 12545

Parisi, R., Symmons, D. P. M., Griffiths, C. E. M., and Ashcroft, D. M. (2013). Global epidemiology of psoriasis: a systematic review of incidence and prevalence. J. Invest. Dermatol. 133, 377-385. doi: 10.1038/jid.2012.339

Peguet-Navarro, J., Dezutter-Dambuyant, C., Buetler, T. M., Leclaire, J., Smola, H., Blum, S., et al. (2008). Supplementation with oral probiotic bacteria protects human cutaneous immune homeostasis after UV exposure - double blind, randomized, placebo controlled clinical trial. Eur. J. Dermatol. 18, 504-511. doi: 10.1684 /ejd.2008.0496

Petra, A. I., Panagiotidou, S., Hatziagelaki, E., Stewart, J. M., Conti, P., and Theoharides, T. C. (2015). Gut-microbiota-brain axis and its effect on neuropsychiatric disorders with suspected immune dysregulation. Clin. Ther. 37, 984-995. doi: 10.1016/j.clinthera.2015.04.002

Philippe, D., Blum, S., and Benyacoub, J. (2011). Oral Lactobacillus paracasei improves skin barrier function recovery and reduces local skin inflammation. Eur. J. Dermatol. 21, 279-280. doi: 10.1684/ejd.2010.1242

Picardo, M., Eichenfield, L. F., and Tan, J. (2017). Acne and Rosacea. Dermatol. Ther. (Heidelb). 7(Suppl. 1), 43-52. doi: 10.1007/s13555-016-0168-8

Pittayapruek, P., Meephansan, J., Prapapan, O., Komine, M., and Ohtsuki, M. (2016). Role of matrix metalloproteinases in photoaging and photocarcinogenesis. Int. J. Mol. Sci. 17:868. doi: 10.3390/ijms170 60868
Poutahidis, T., Kearney, S. M., Levkovich, T., Qi, P., Varian, B. J., Lakritz, J. R., et al. (2013). Microbial symbionts accelerate wound healing via the neuropeptide hormone oxytocin. PLoS One 8:e78898. doi: 10.1371/journal.pone. 0078898

Prakash, P., Mohite, A., and Gautam, P. A. (2016). study of presence of depression in acne vulgaris patients. GJRA 5, 107-109. doi: 10.15373/22778160

Purchiaroni, F., Tortora, A., Gabrielli, M., Bertucci, F., Gigante, G., Ianiro, G., et al. (2013). The role of intestinal microbiota and the immune system. Eur. Rev. Med. Pharmacol. Sci. 17, 323-333.

Qin, Z., Balimunkwe, R. M., and Quan, T. (2017). Age-related reduction of dermal fibroblast size up-regulates multiple matrix metalloproteinases as observed in aged human skin in vivo. Br. J. Dermatol. 177, 1337-1348. doi: 10.1111/bjd. 15379

Quan, T., Little, E., Quan, H., Qin, Z., Voorhees, J. J., and Fisher, G. J. (2013). Elevated matrix metalloproteinases and collagen fragmentation in photodamaged human skin: impact of altered extracellular matrix microenvironment on dermal fibroblast function. J. Invest. Dermatol. 133, 1362-1366. doi: 10.1038/jid.2012.509

Rachakonda, T. D., Schupp, C. W., and Armstrong, A. W. (2014). Psoriasis prevalence among adults in the United States. J. Am. Acad. Dermatol. 70, 512-516. doi: 10.1016/j.jaad.2013.11.013

Rajilić-Stojanović, M., and de Vos, W. M. (2014). The first 1000 cultured species of the human gastrointestinal microbiota. FEMS Microbiol. Rev. 38, 996-1047. doi: 10.1111/1574-6976.12075

Ramírez-Boscá, A., Navarro-López, V., Martínez-Andrés, A., Such, J., Francés, R., de la Parte, J. H., et al. (2015). Identification of bacterial DNA in the peripheral blood of patients with active psoriasis. JAMA Dermatol. 151, 670-671. doi: 10.1001/jamadermatol.2014.5585

Ramrakha, S., Fergusson, D. M., Horwood, L. J., Dalgard, F., Ambler, A., Kokaua, J., et al. (2016). Cumulative mental health consequences of acne: 23 -year followup in a general population birth cohort study. Br. J. Dermatol. 175, 1079-1081. doi: $10.1111 /$ bjd. 13786

Rather, I. A., Bajpai, V. K., Kumar, S., Lim, J., Paek, W. K., and Park, Y. (2016). Probiotics and atopic dermatitis: an overview. Front. Microbiol. 7:507. doi: $10.3389 /$ fmicb.2016.00507

Roberson, E. D. O., and Bowcock, A. M. (2010). Psoriasis genetics: breaking the barrier. Trends Genet. 26, 415-423. doi: 10.1016/j.tig.2010. 06.006

Rodan, K., Fields, K., and Falla, T. J. (2017). Efficacy of a twice-daily, 3-step, overthe-counter skincare regimen for the treatment of acne vulgaris. Clin. Cosmet. Investig. Dermatol. 10, 3-9. doi: 10.2147/CCID.S125438

Rokowska-Waluch, A., Pawlaczyk, M., Cybulski, M., Zurawski, J., Kaczmarek, M., Michalak, M., et al. (2016). Stressful events and serum concentration of substance P in acne patients. Ann. Dermatol. 28, 464-469. doi: 10.5021/ad.2016. 28.4.464

Rook, G. A. W. (2012). Hygiene hypothesis and autoimmune diseases. Clin. Rev. Allergy Immunol. 42, 5-15. doi: 10.1007/s12016-011-8285-8

Samuelson, D. R., Welsh, D. A., and Shellito, J. E. (2015). Regulation of lung immunity and host defense by the intestinal microbiota. Front. Microbiol. 6:1085. doi: 10.3389/fmicb.2015.01085

Sánchez, B., Delgado, S., Blanco-Míguez, A., Lourenço, A., Gueimonde, M., and Margolles, A. (2017). Probiotics, gut microbiota, and their influence on host health and disease. Mol. Nutr. Food Res. 61:1600240. doi: 10.1002/mnfr. 201600240

Sarao, L. K., and Arora, M. (2017). Probiotics, prebiotics, and microencapsulation: a review. Crit. Rev. Food Sci. Nutr. 57, 344-371. doi: 10.1080/10408398.2014. 887055

Scher, J. U., Ubeda, C., Artacho, A., Attur, M., Isaac, S., Reddy, S. M., et al. (2015). Decreased bacterial diversity characterizes the altered gut microbiota in patients with psoriatic arthritis, resembling dysbiosis in inflammatory bowel disease. Arthritis Rheumatol. 67, 128-139. doi: 10.1002/art.38892

Schwarz, A., Bruhs, A., and Schwarz, T. (2017). The short-chain fatty acid sodium butyrate functions as a regulator of the skin immune system. J. Investig. Dermatol. 1, 855-864. doi: 10.1016/j.jid.2016.11.014

Seite, S., and Bieber, T. (2015). Barrier function and microbiotic dysbiosis in atopic dermatitis. Clin. Cosmet. Investig. Dermatol. 8, 479-483. doi: 10.2147/CCID. S91521 
Shah, K. R., Boland, C. R., Patel, M., Thrash, B., and Menter, A. (2013). Cutaneous manifestations of gastrointestinal disease: part I. JAAD 68, 189.e1-189.e21. doi: 10.1016/j.jaad.2012.10.037

Shu, M., Wang, Y., Yu, J., Kuo, S., Coda, A., Jiang, Y., et al. (2013). Fermentation of Propionibacterium acnes, a commensal bacterium in the human skin microbiome, as skin probiotics against methicillin-resistant Staphylococcus aureus. PLoS One 8:e55380. doi: 10.1371/journal.pone. 0055380

Simpson, E. L., Chalmers, J. R., Hanifin, J. M., Thomas, K. S., Cork, M. J., McLean, W. H. I., et al. (2014). Emollient enhancement of the skin barrier from birth offers effective atopic dermatitis prevention. J. Allergy Clin. Immunol. 134, 818-823. doi: 10.1016/j.jaci.2014.08.005

Sirisinha, S. (2016). The potential impact of gut microbiota on your health: current status and future challenges. Asian Pac. J. Allergy Immunol. 34, 249-264. doi: 10.12932/AP0803

Sironi, M., and Clerici, M. (2010). The hygiene hypothesis: an evolutionary perspective. Microbes Infect. 12, 421-427. doi: 10.1016/j.micinf.2010.02.002

Siver, R. (1961). Lactobacillus for the control of acne. J. Med. Soc. New Jersey 59, 52-53.

Sokol, H., Pigneur, B., Watterlot, L., Lakhdari, O., Bermúdez-Hamarán, L. G., Gratadoux, J., et al. (2008). Faecalibacterium prausnitzii is an anti-inflammatory commensal bacterium identified by gut microbiota analysis of Crohn disease patients. Proc. Natl. Acad. Sci. U.S.A. 105, 16731-16736. doi: 10.1073/pnas. 0804812105

Song, H., Yoo, Y., Hwang, J., Na, Y., and Kim, H. S. (2016). Faecalibacterium prausnitzii subspecies-level dysbiosis in the human gut microbiome underlying atopic dermatitis. J. Allergy Clin. Immunol. 137, 852-860. doi: 10.1016/j.jaci. 2015.08.021

Stokes, J. H., and Pillsbury, D. M. (1930). The effect on the skin of emotional and nervous states: iII. Theoretical and practical consideration of a gastro-intestinal mechanism. Arch. Derm. Syphilol. 22, 962-993. doi: 10.1001/archderm.1930. 01440180008002

Strachan, D. P. (1989). Hay fever, hygiene, and household size. BMJ 299, 1259-1260. doi: 10.1136/bmj.299.6710.1259

Takeshita, J., Grewal, S., Langan, S. M., Mehta, N. N., Ogdie, A., Van Voorhees, A. S., et al. (2017). Psoriasis and comorbid diseases: epidemiology. J. Am. Acad. Dermatol. 76, 377-390. doi: 10.1016/j.jaad.2016. 07.064

Tan, J. K. L., and Bhate, K. (2015). A global perspective on the epidemiology of acne. Br. J. Dermatol. 172(Suppl. 1), 3-12. doi: 10.1111/bjd.13462

Theodorou, V., Ait-Belgnaoui, A., Agostini, S., and Eutamene, H. (2014). Effect of commensals and probiotics on visceral sensitivity and pain in irritable bowel syndrome. Gut Microbes 5, 430-436. doi: 10.4161/gmic.29796

Thomas, C. M., and Versalovic, J. (2010). Probiotics-host communication: modulation of signaling pathways in the intestine. Gut Microbes 1, 148-163. doi: 10.4161/gmic.1.3.11712

Thrash, B., Patel, M., Shah, K. R., Boland, C. R., and Menter, A. (2013). Cutaneous manifestations of gastrointestinal disease: part II. JAAD 68, 211.e1-211.e33. doi: 10.1016/j.jaad.2012.10.036

Van Beelen, A. J., Teunissen, M. B., Kapsenberg, M. L., and de Jong, E. C. (2007). Interleukin-17 in inflammatory skin disorders. Curr. Opin. Allergy Clin. Immunol. 7, 374-381. doi: 10.1097/ACI.0b013e3282 ef869e

Vaughn, A. R., Notay, M., Clark, A. K., and Sivamani, R. K. (2017). Skin-gut axis: the relationship between intestinal bacteria and skin health. World J. Dermatol. 6, 52-58. doi: 10.5314/wjd.v6.i4.52

Verstockt, B., Van Assche, G., Vermeire, S., and Ferrante, M. (2016). Biological therapy targeting the IL-23/IL-17 axis in inflammatory bowel disease. Exp. Opin. Biol. Ther. 17, 31-47. doi: 10.1080/14712598.2017.1258399
Vijayashankar, M., and Raghunath, N. (2012). Pustular psoriasis responding to probiotics - A new insight. Our Dermatol. 3, 326-329. doi: 10.7241/ourd. 20124.71

Volkova, L. A., Khalif, I. L., and Kabanova, I. N. (2001). Impact of the impaired intestinal microflora on the course of acne vulgaris. Klin. Med. (Mosk). 79, 39-41.

Weaver, C. T., Elson, C. O., Fouser, L. A., and Kolls, J. K. (2013). The Th17 pathway and inflammatory diseases of the intestines, lungs, and skin. Annu. Rev. Pathol. 24, 477-512. doi: 10.1146/annurev-pathol-011110-130318

Wesemann, D. R., and Nagler, C. R. (2016). The microbiome, timing, and barrier function in the context of allergic disease. Immunity 44, 728-738. doi: 10.1016/ j.immuni.2016.02.002

Wiegand, C., Raschke, C., and Elsner, P. (2016). "Skin aging: a brief summary of characteristic changes," in Textbook of Aging Skin, eds M. A. Farage, K. W. Miller, and H. I. Maibach (Berlin: springer).

Won, T. J., Kim, B., Lim, Y. T., Song, D. S., Park, S. Y., Park, E. S., et al. (2011). Oral administration of Lactobacillus strains from Kimchi inhibits atopic dermatitis in NC/Nga mice. J. Appl. Microbiol. 110, 1195-1202. doi: 10.1111/j.1365-2672. 2011.04981.x

Wu, G. D., and Lewis, J. D. (2013). Analysis of the human gut microbiome and association with disease. Clin. Gastroenterol. Hepatol. 11, 774-777. doi: 10.1016/ j.cgh.2013.03.038

Xia, W., Quan, T., Hammerberg, C., Voorhees, J. J., and Fisher, G. J. (2015). A mouse model of skin aging: fragmentation of dermal collagen fibrils and reduced fibroblast spreading due to expression of human matrix metalloproteinase-1. J. Dermatol. Sci. 78, 79-82. doi: 10.1016/j.jdermsci.2015. 01.009

Yentzer, B. A., Hick, J., Reese, E. L., Uhas, A., Feldman, S. R., and Balkrishnan, R. (2010). Acne vulgaris in the United States: a descriptive epidemiology. Cutis 86, 94-99.

You, G. E., Jung, B. J., Kim, H. R., Kim, H. G., Kim, T. R., and Chung, D. K. (2013). Lactobacillus sakei lipoteichoic acid inhibits MMP-1 induced by UVA in normal dermal fibroblasts of human. J. Microbiol. Biotechnol. 23, 1357-1364. doi: 10.4014/jmb.1306.06026

Zaenglein, A. L., Pathy, A. L., Schlosser, B. J., Alikhan, A., Baldwin, H. E., Berson, D. S., et al. (2016). Guidelines of care for the management of acne vulgaris. J. Am. Acad. Dermatol. 74, 945-973. doi: 10.1016/j.jaad.2015.12.037

Zhang, H., Liao, W., Chao, W., Chen, Q., Zeng, H., Wu, C., et al. (2008). Risk factors for sebaceous gland diseases and their relationship to gastrointestinal dysfunction in Han adolescents. J. Dermatol. 35, 555-561. doi: 10.1111/j.13468138.2008.00523.X

Zhang, L., Li, Y., Li, Y., Qi, L., Liu, X., Yuan, C., et al. (2012). Increased frequencies of Th22 cells as well as Th17 cells in the peripheral blood of patients with ankylosing spondylitis and rheumatoid arthritis. PLoS One 7:e31000. doi: 10.1371/journal.pone.0031000

Zouboulis, C. C. (2014). Acne as a chronic systemic disease. Clin. Dermatol. 32, 389-396. doi: 10.1016/j.clindermatol.2013.11.005

Conflict of Interest Statement: The authors declare that the research was conducted in the absence of any commercial or financial relationships that could be construed as a potential conflict of interest.

Copyright (c) 2018 Salem, Ramser, Isham and Ghannoum. This is an open-access article distributed under the terms of the Creative Commons Attribution License (CC BY). The use, distribution or reproduction in other forums is permitted, provided the original author(s) and the copyright owner(s) are credited and that the original publication in this journal is cited, in accordance with accepted academic practice. No use, distribution or reproduction is permitted which does not comply with these terms. 